\title{
دراسة اصطفائية لتعليم اللسان العربي للأجانب
}

\author{
د.عبد المُحسن عليّ القيسي'

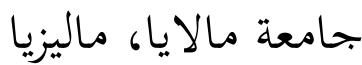 \\ knowledgeableor@gmail.com
}

\section{الملنّّص}

إنَّ تعليم اللسان العربي للأجانب يستلزم تطوير المناهج ‘ المُعدة لذلك، وهذا من الأهمية بمكان إذْ تُعد القطب الذي تدور حوله الرحى، ذلك لأنَّ سلامتها يعني بناحها؛

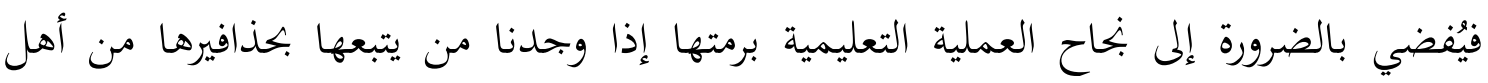

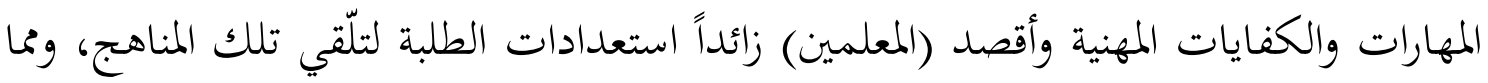
يشار إليه في هذا الجمال سامة منهجية كتاب "العربية بين يديك" حسن السمعة الذي بسببه

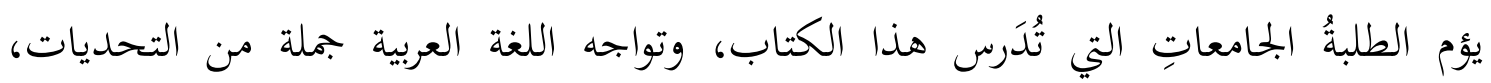
وأخطرها التحديات الخارجية، وهي كثيرة في زمن العولمة التي تسعى إلى القضاء على التنوع اللساني في العالم. ولذا السبب جاءتْ هذه الدراسة لتسلط الضوء على إشكالية تطوير مناهج؛ تعليم اللسان العربي للأجحانب والمتمثلة بضعف مستوى المناهج من جهة وقلة المعلمين الماهرين من

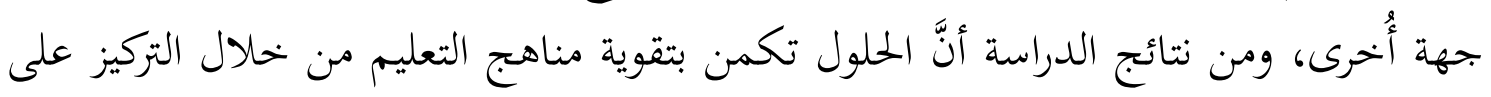

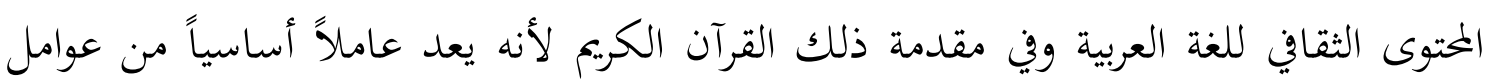

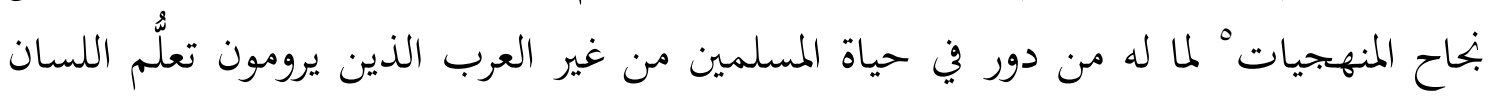
العربي من أجل الدين الإسلامي وكتابه المجيد. ويتبع الباحث المنهج التحليلي والنقدي في هذه

باحث أكاديمي متخصص ب(فقه اللغة العربية والدراسات القرآنية)، حاصل على Y دكتوراه فلسفة، الأولى في بحال فقه اللغة العربية والثانية في بحال الدراسات القرآنية، مُقيم في ماليزيا لنشر اللغة العربية البميدة.

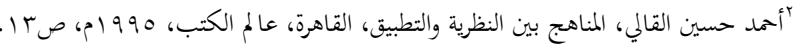

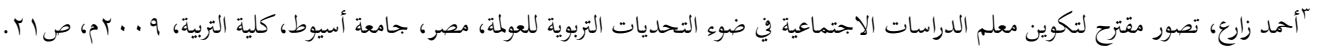

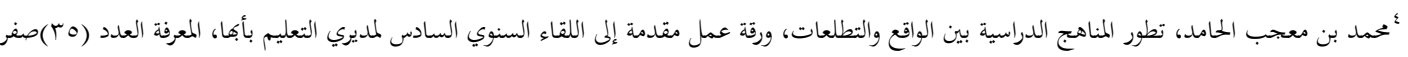

. \& ص ص (ه) 19

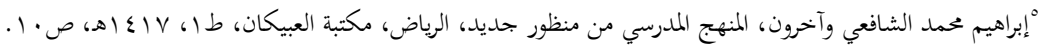


الدراسة التي انتظمت بثلاث مباحث مسبوقة بمقدمة تمهيدية ذكرتُ فيها المنطلق الفكري وما

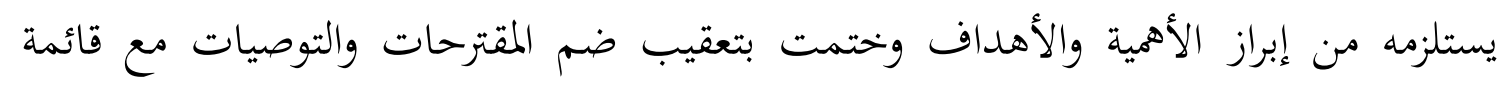
بمعادر الدراسة.

المقدمة التمهيدية

هذه دراسة اصطفائية` لتعليم اللسان العربي للأجانب، وأقصد بها انتقائية، حيث

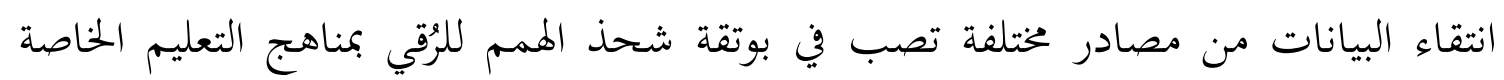

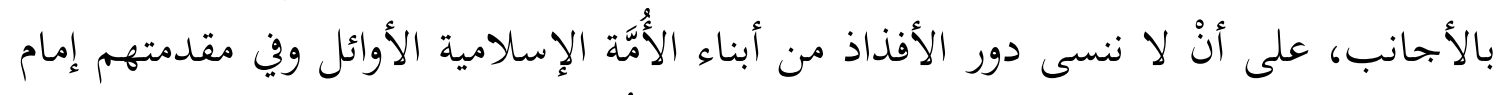

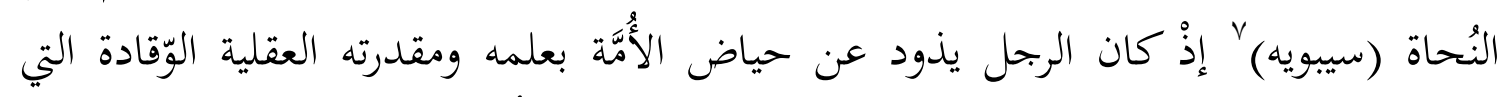

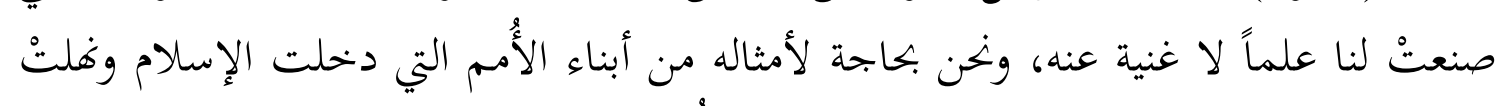

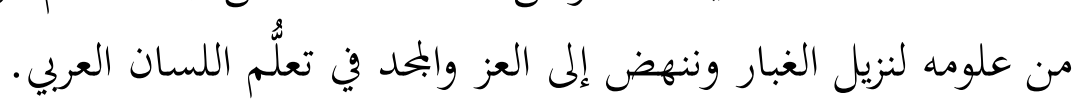

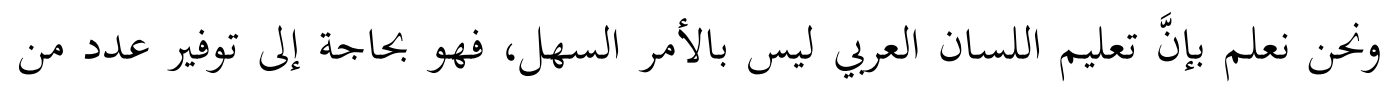

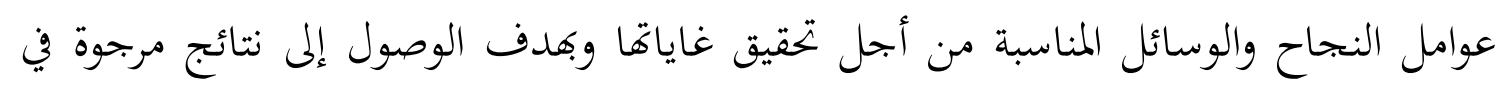

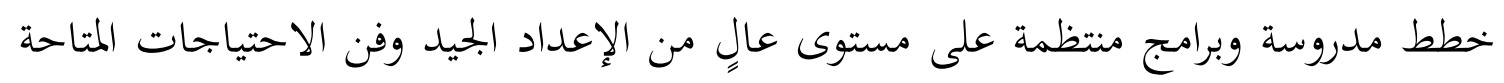

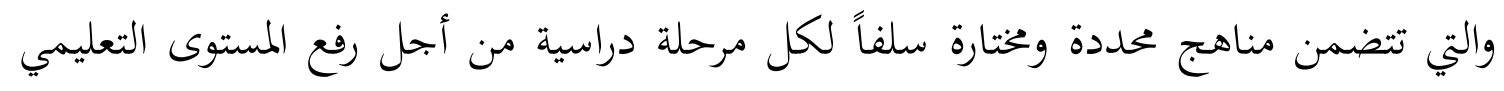

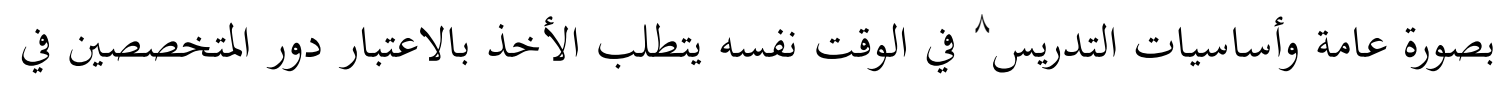

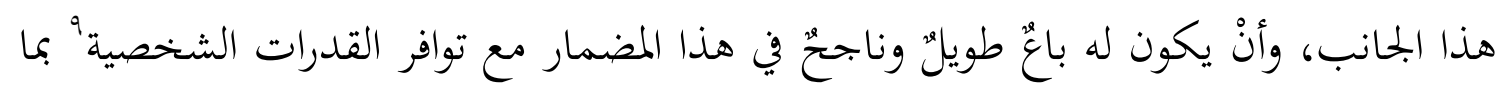

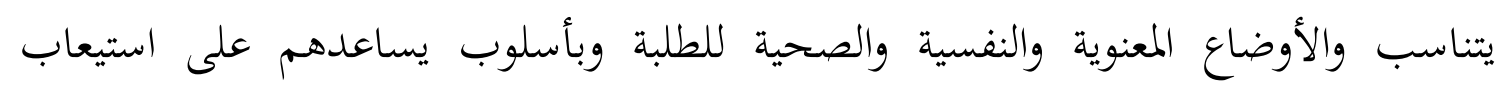

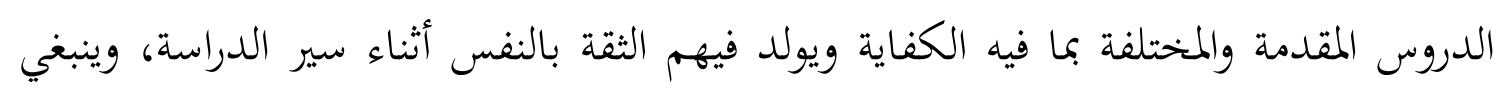

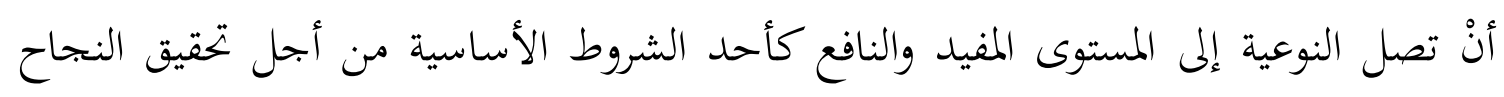

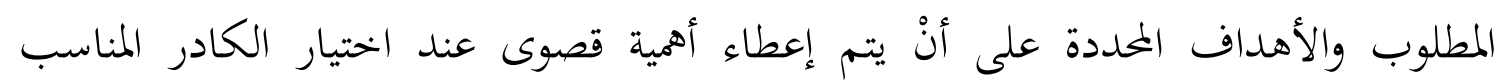

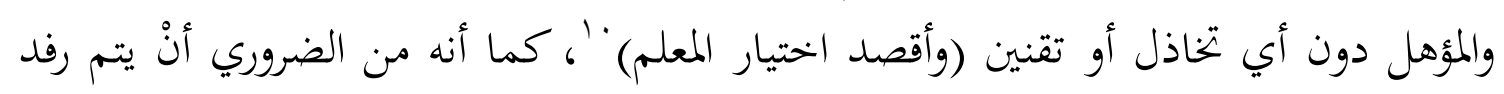

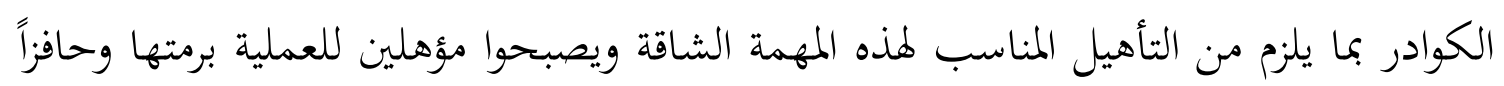


قوياً ومهماً يساعد على المزيد من العطاء وتقديم ما لديهم بسخاء"'، ويفضل أنْ تشكل لجنة

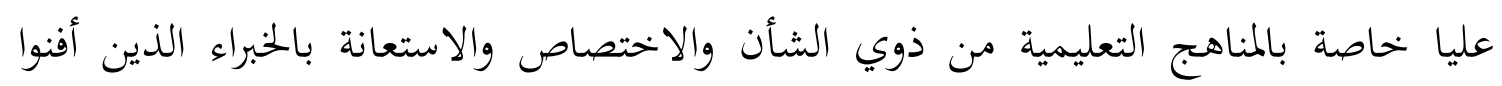

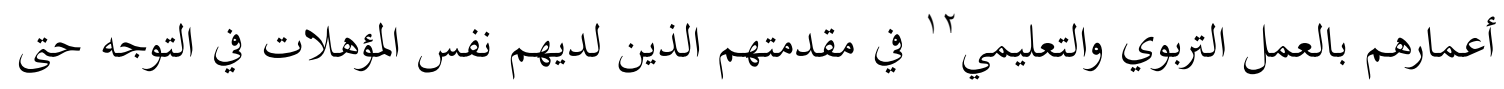

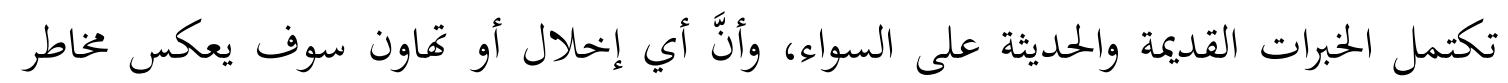

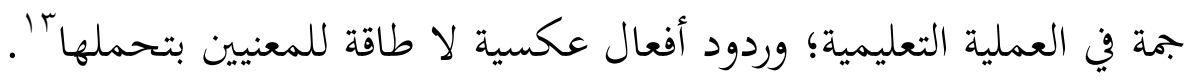

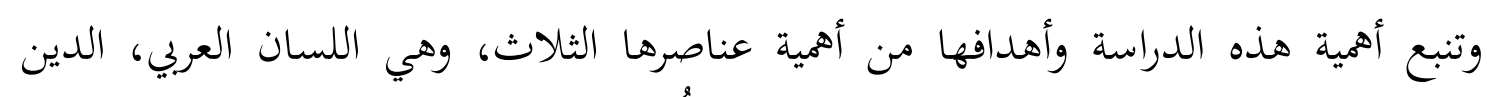

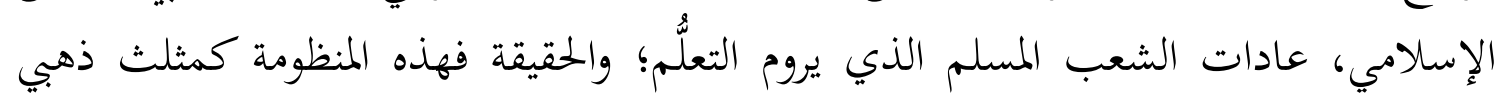

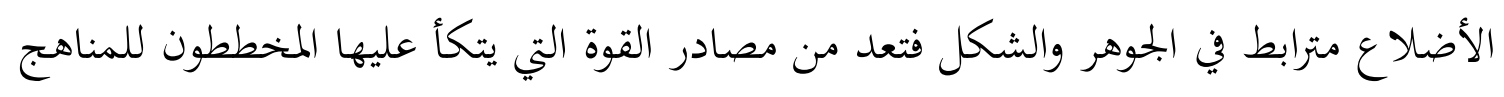
التعليمية.

وستضيف هذه الدراسة ذخيرة علمية إلى المكتبات العربية والمراكز العلمية ملاحظات فيها

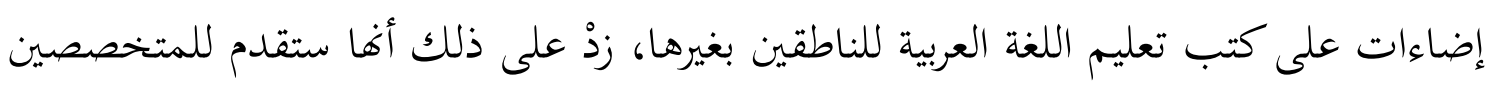

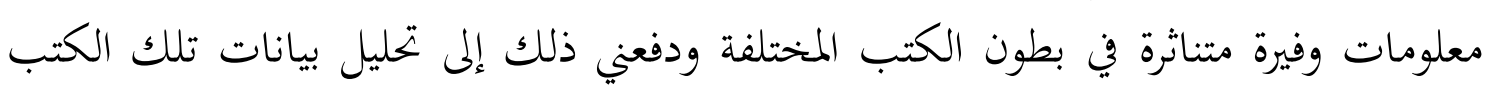

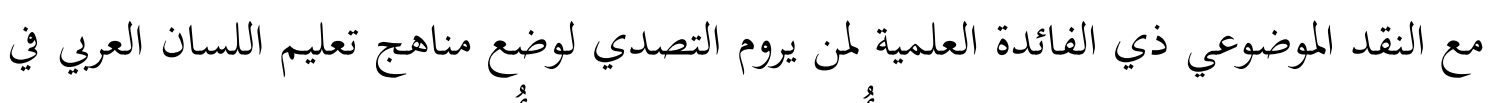

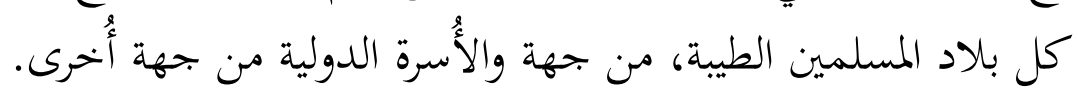

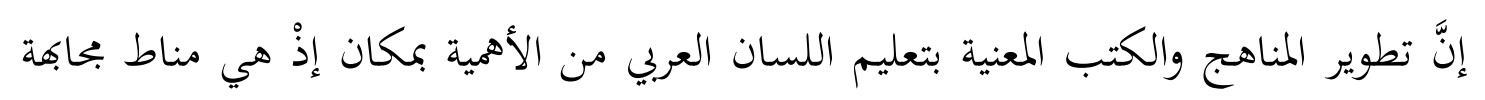

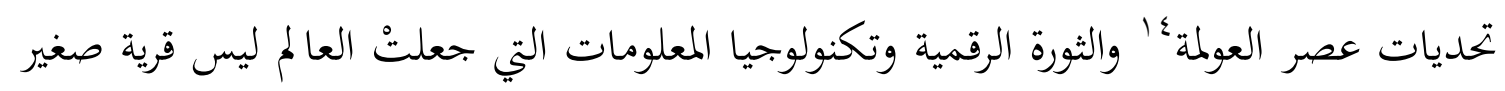

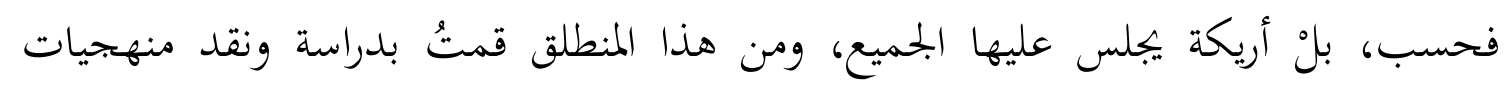

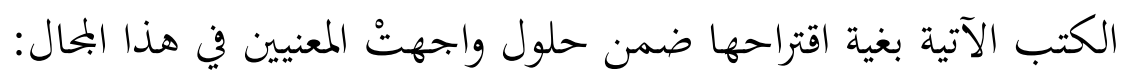

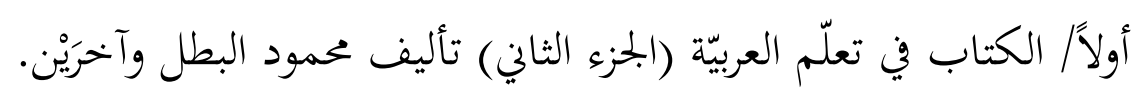

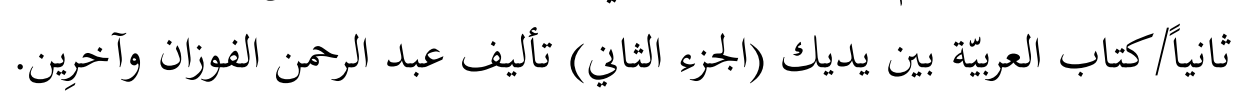

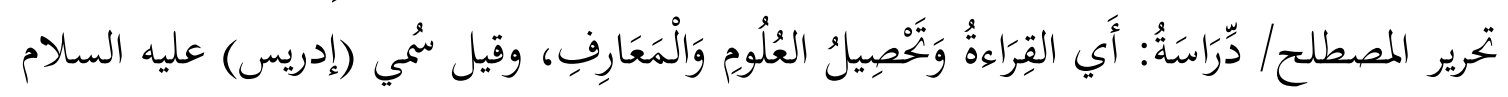

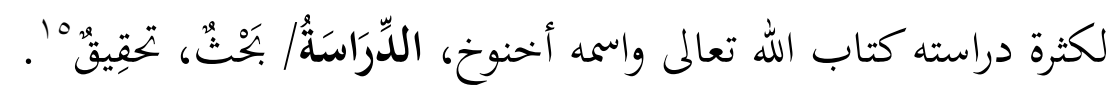

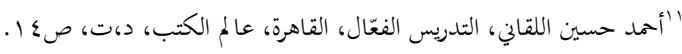

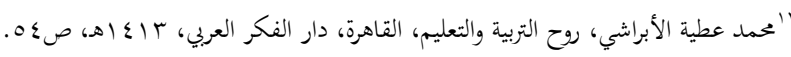

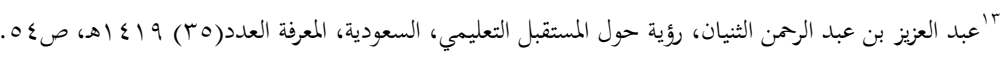

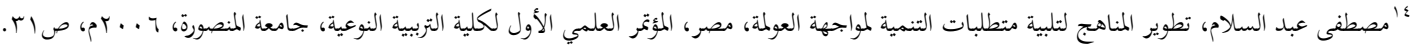

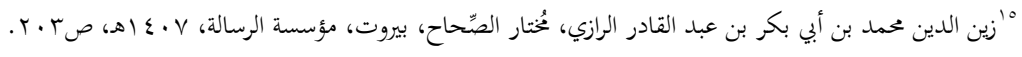


اصطفائية"1 : يعني عمل انتقائي، مؤلف من عناصر مستمدة من مصادر مختلفة، وهذا يعني أنَّ

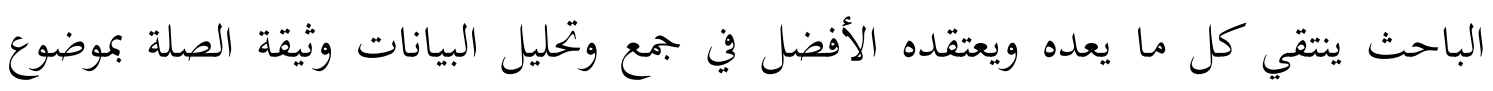
الدراسة. أهمية تعلُّم اللسان العربي فله أهمية كبرى لدى المسلمين، إذْ هو اللسان المُقدّدس كونه كلام الله تعالى، ولا تتم الصالاة

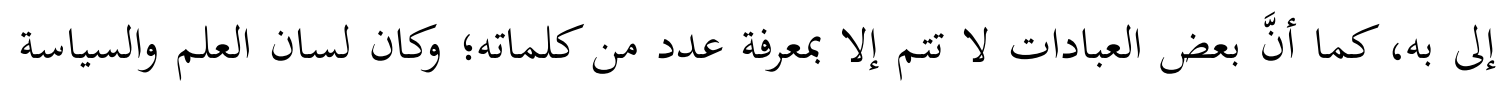
والأدب والتجارة طيلة قرون في الدول الإسلامية التي حكمها المسلمون؛ ولأهميته فإنَّ له تأثيرا

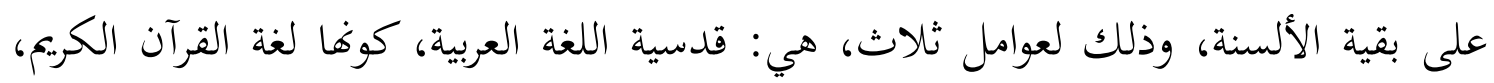

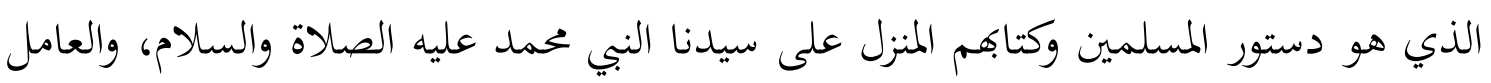

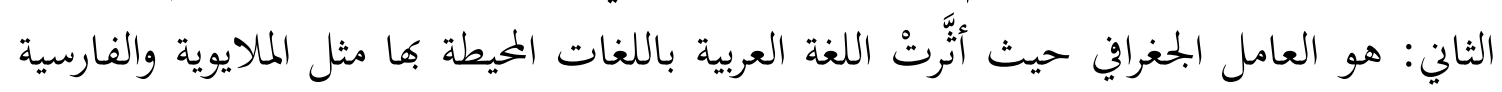
والتركية والبربرية وغيرها، إضافة إلى عامل التجارة، وفي عصرنا السياحة والسياسة وغير ذلئ ذلك.

\section{اللغة العربية في العصر الحاضر}

تواجه اللغة العربية جملة من التحديات، منها ما هي تحديات داخلية، من هجر أهلها

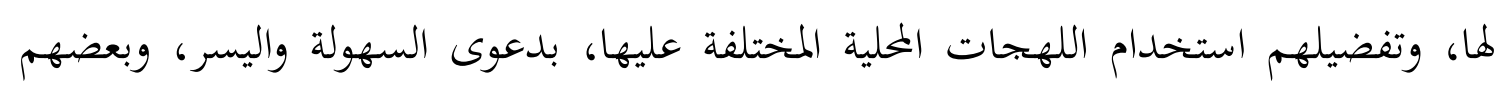

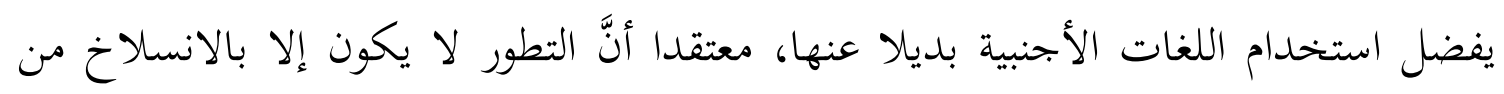

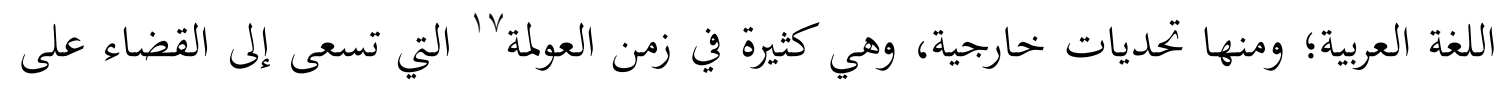

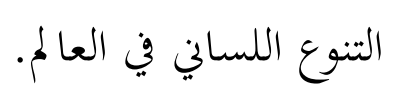

ولكثرة هذه التحديات وقوتا، تظهر اللغة العربية وكأها عاجزة عن اللحاق بركب التطور

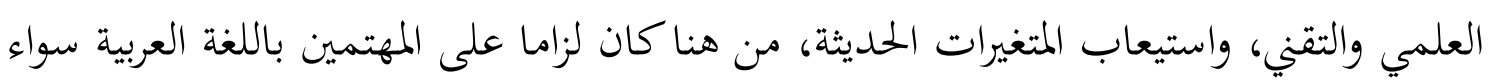

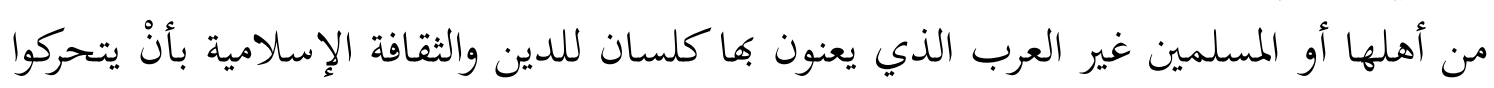

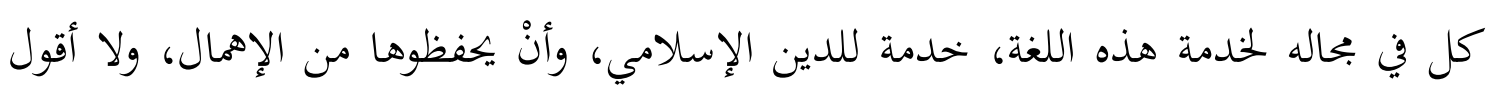
من الضياع، فقد تكفل الله تعالى بحفظها.

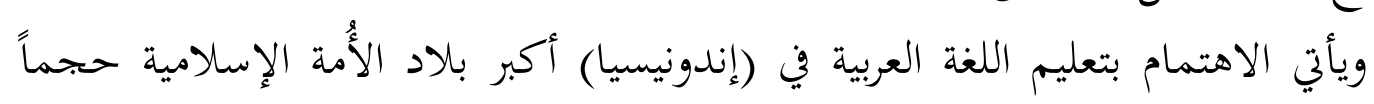

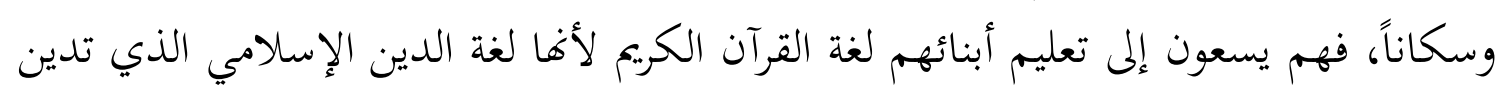


به الأغلبية المسلمة في بلادهم الطيبة، وتنوع عاداتم في أخلاقيات كريمة هي من جوهر العربية

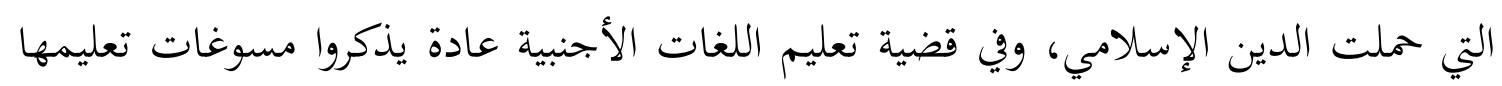

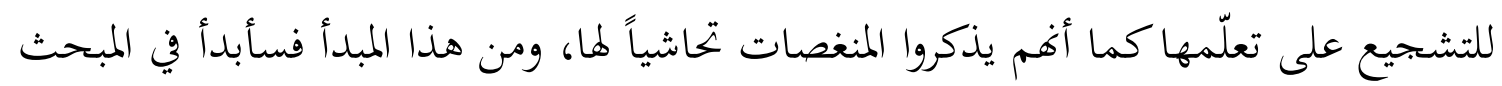

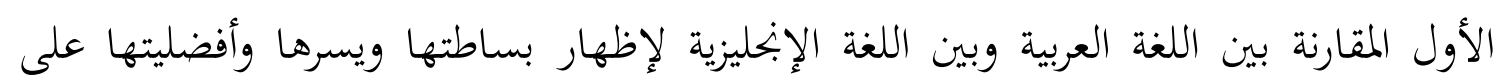

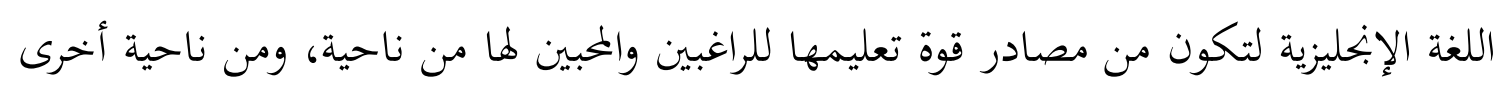

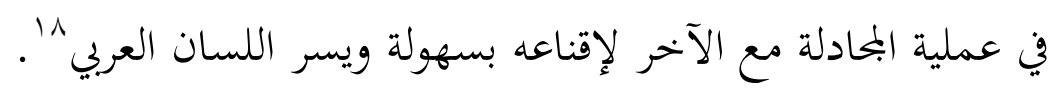

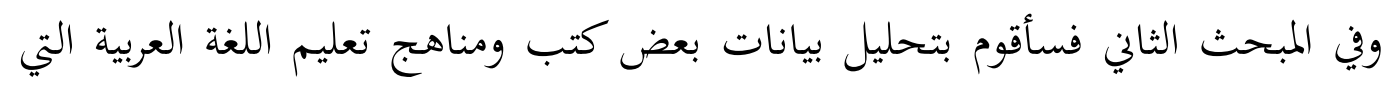

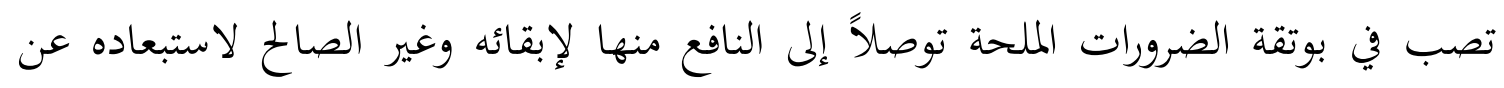

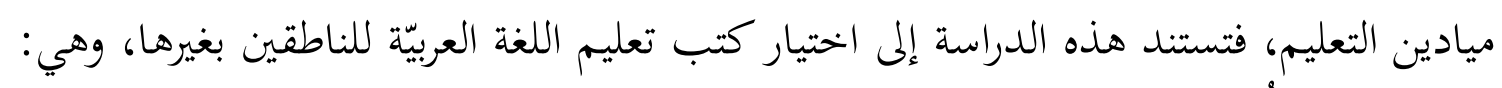

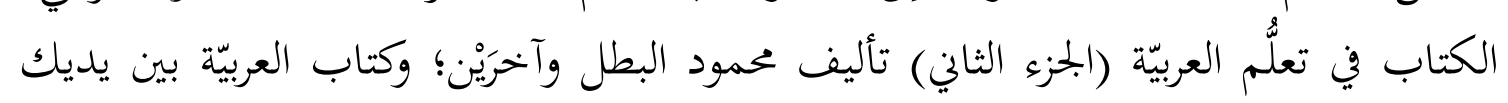

$$
\text { (الجزء الثاني) تأليف عبد الرحمن الفوزان وآخرِين. }
$$

وفي المبحث الثالث فسأذكر الجوانب النظرية والتطبيقية اللازم توفرها في كتب النبان تعليم العربية

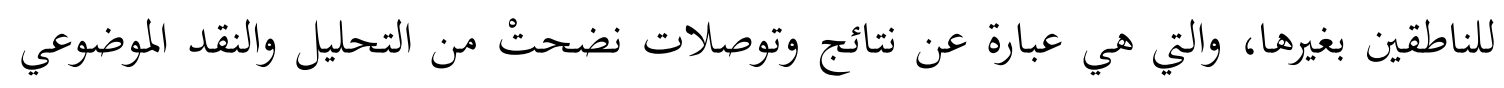
للمنهجيات سالفة الذكر.

\section{المبحث الأول: دراسة الفرق بين اللغة العربية واللغة الإنجليزية}

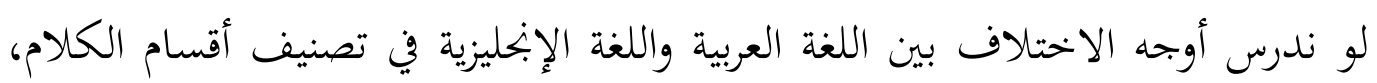

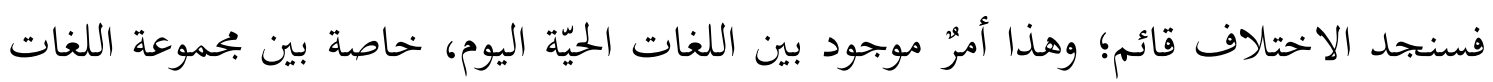

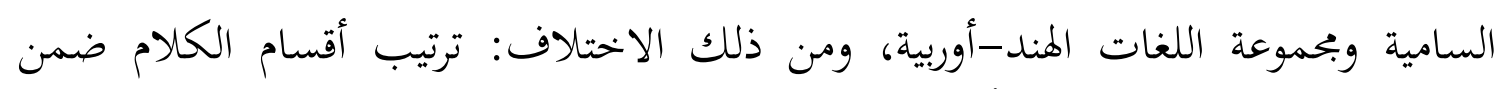

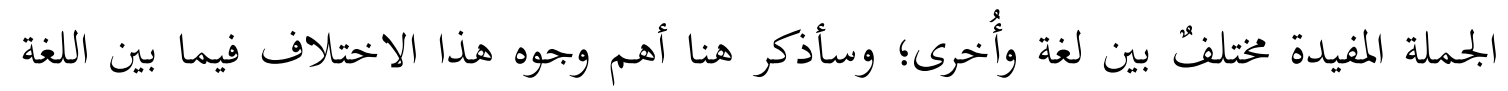

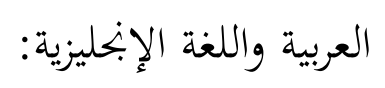

ا.تميل اللغة العربية إلى الجملة الفعلية في الغالب، أي أها تبدأ بالفعل (فعل-فاعل-مفعول

أما الجملة في اللغة الإنحليزية البسيطة، فتقوم على أساس الفاعل (الاسم)

Subject+verb+object أي أغها غالباً جمل اسمية. 


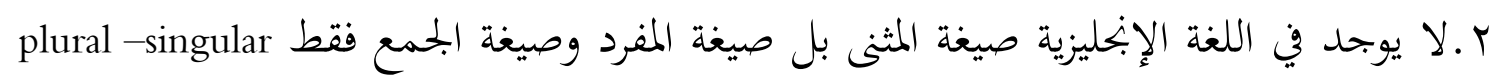

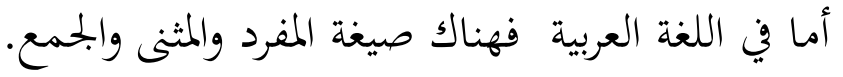

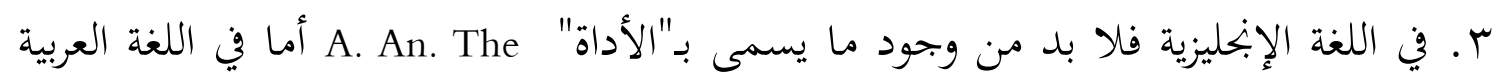

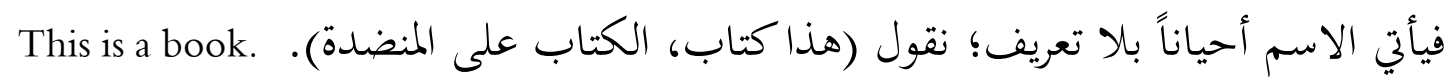
The book is on the table. A red book. عـ الصفة في اللغة الإبحليزية تأتي قبل الموصوف ألمات

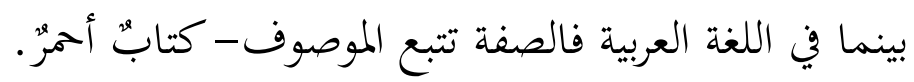

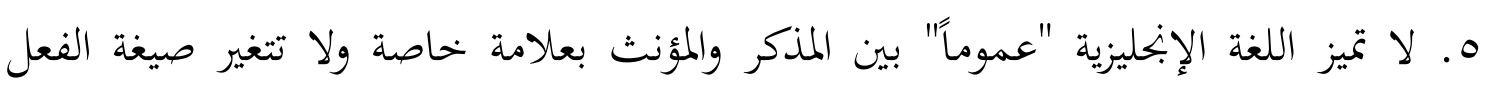
طبقاً لجنس الفاعل كما هو الحال في اللغة العربية.

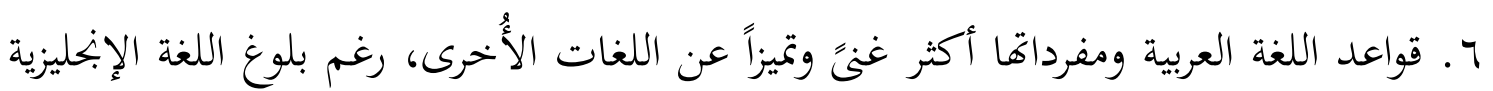

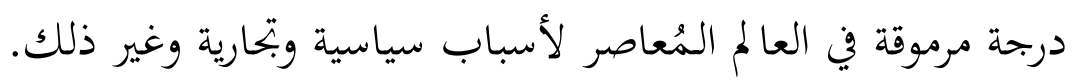

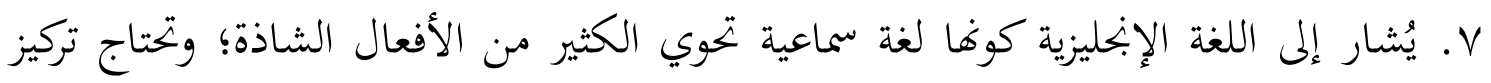

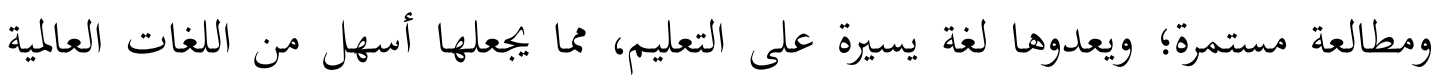

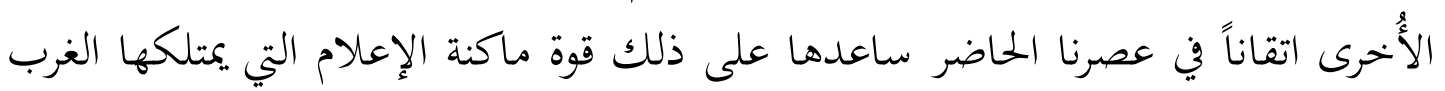
عموما وأمريكيا خصوصاً. 1. هناك دلائل كثيرة ومؤشرات علمية داحضة بالحجة والبرهان تؤكد للمشتغلين بالألسُنية

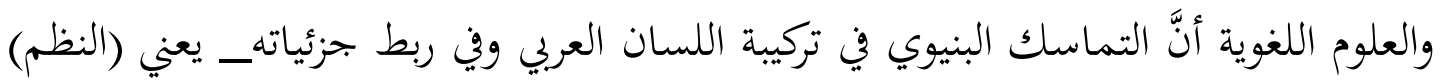

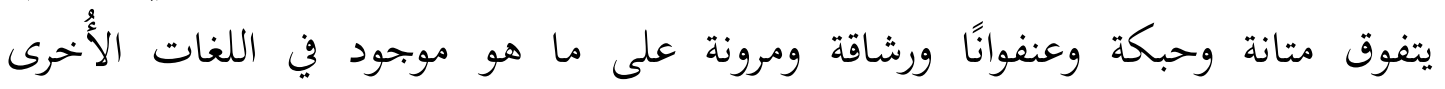

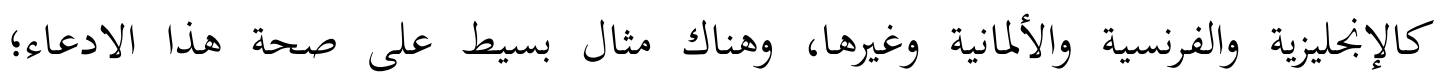

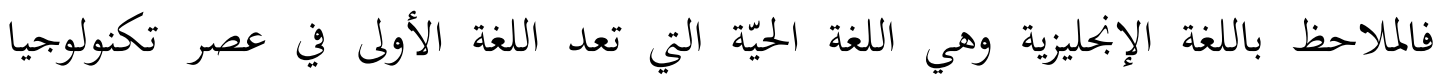

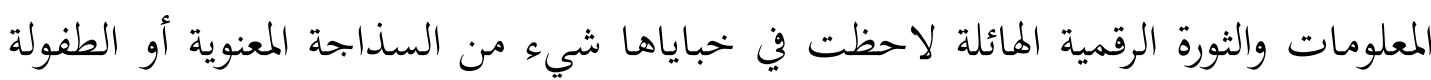

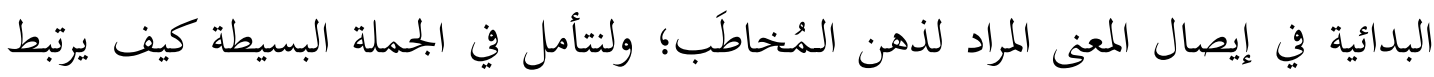

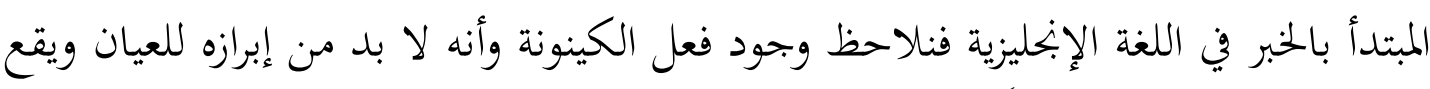

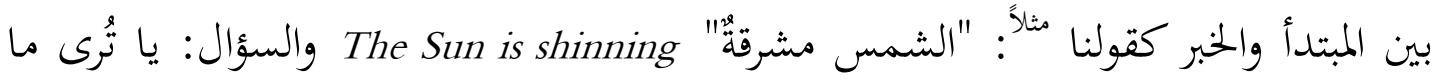
معنى أنْ يظهر الفعل is هنا وبجعله بارزاً؟ فالترجمة الحرفية للجملة الإنحليزية آنفة الذكر

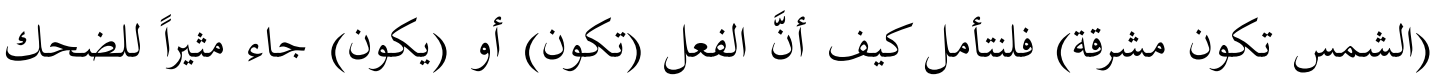

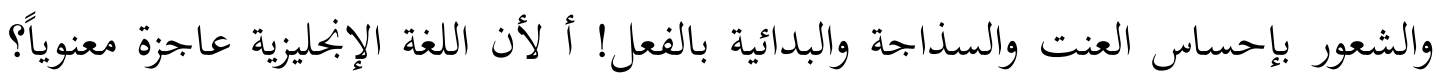

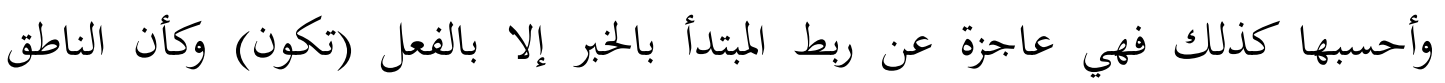


بالإنجليزية لا يقوى على فهم وجود معنى الفعل بحازاً أو ترشيحاً كما هو الحال في اللسان

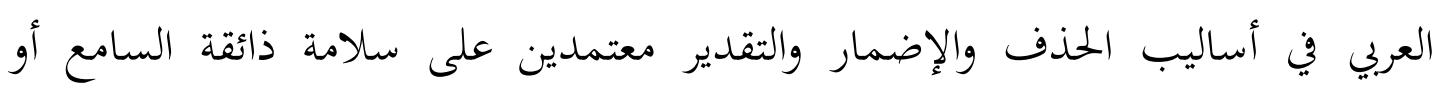

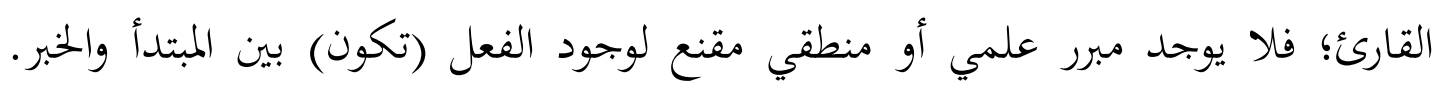

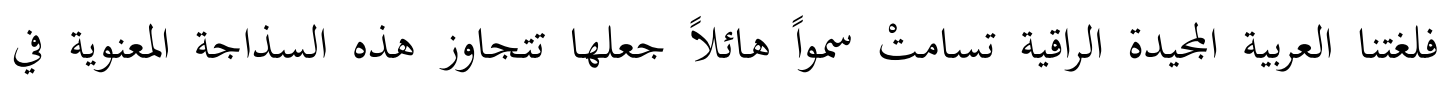

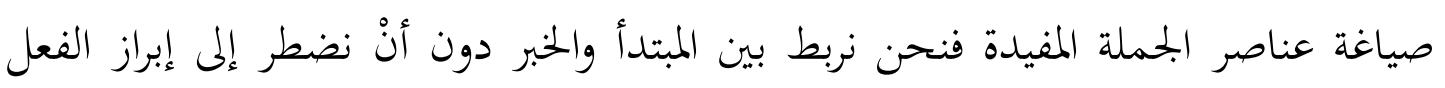

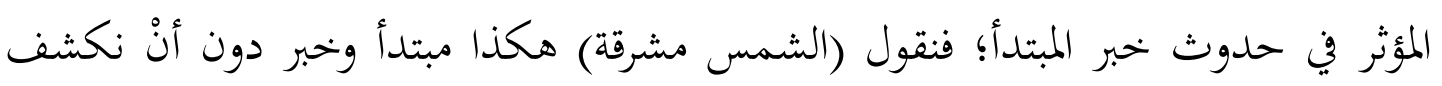

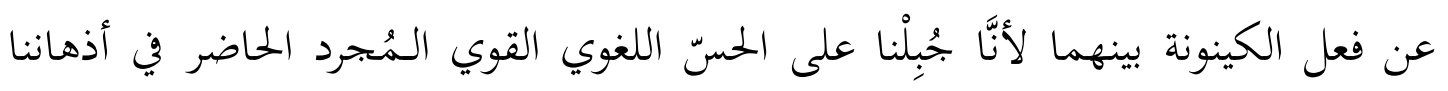

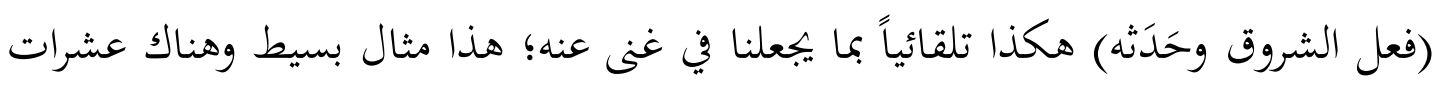

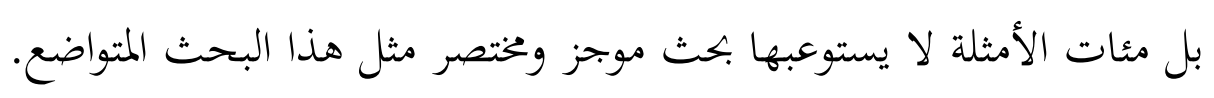

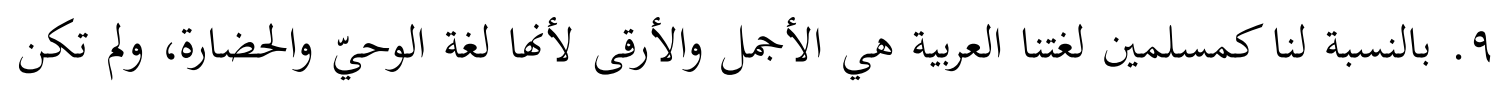

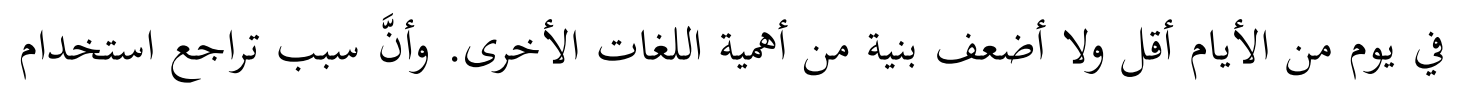

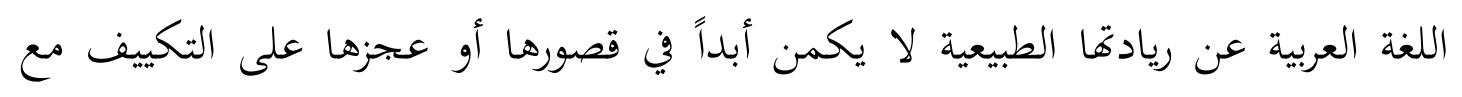

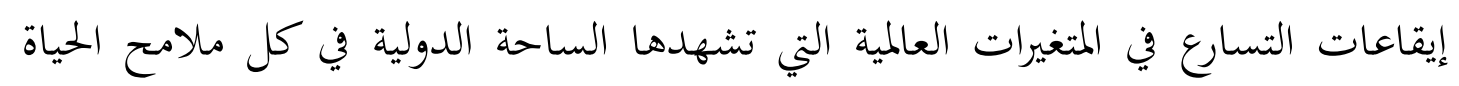

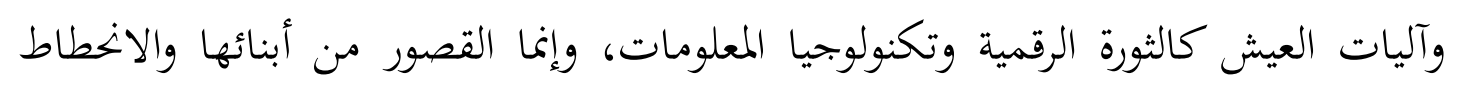

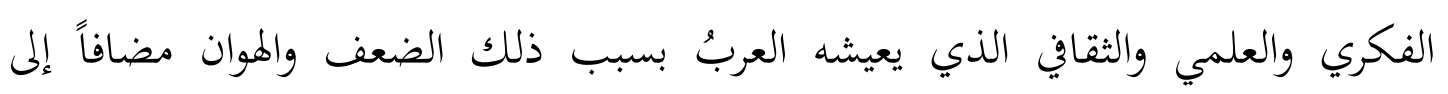
السياسة التي رسمها لنا شانئي الإسلام وبالضرورة ستكون موجهة لوعاء الإسلام (اللسان

المبحث الثاني: تحليل بيانات كتابي تعليم اللغة العربية للناطقين بغيرها.

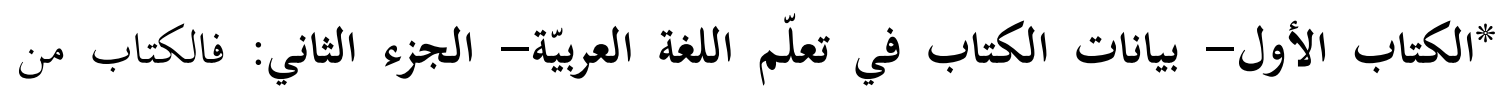

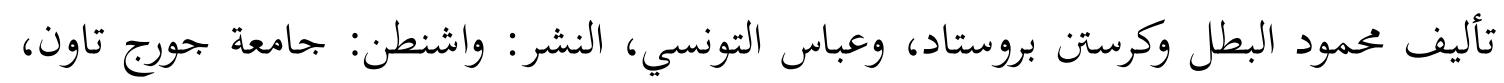

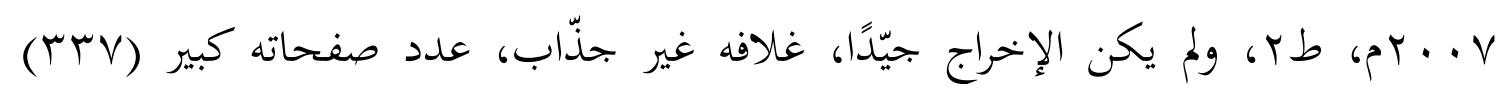

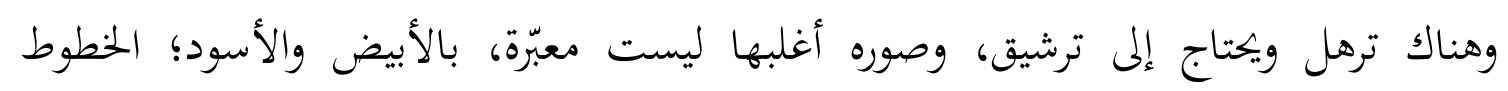
حجمها متوسّط، واضحة، باللون الأسود.

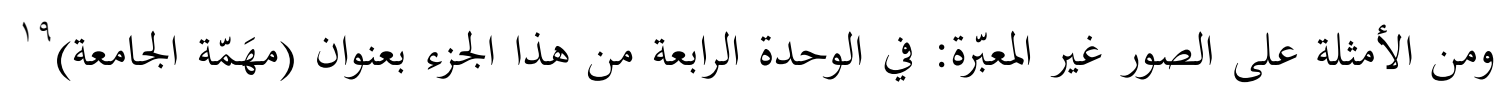

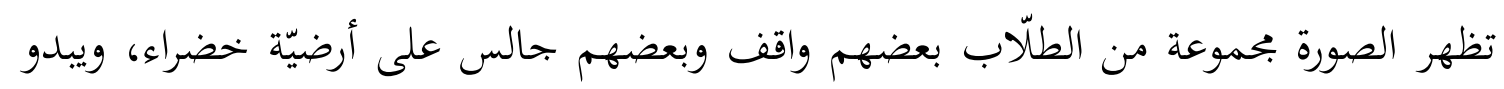

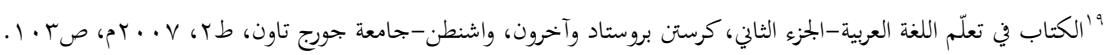


أنّ في الخلفيّة مبنى يتوسّطه قبّة، وهذه الصورة ليست معبّرة عن عنوان الوَحدة، فالأولى أنْ تنتقى صورة أفضل تعبيرًا.

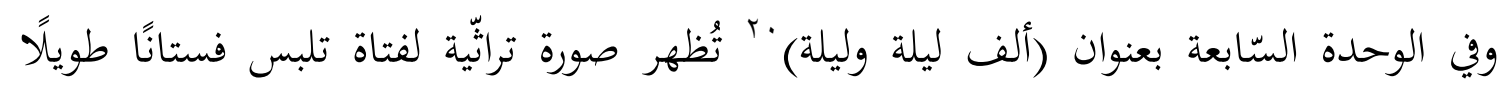

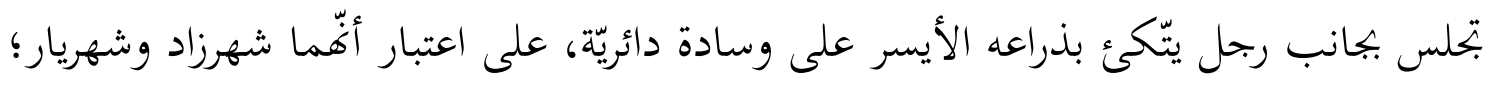
ليست معبّرة.

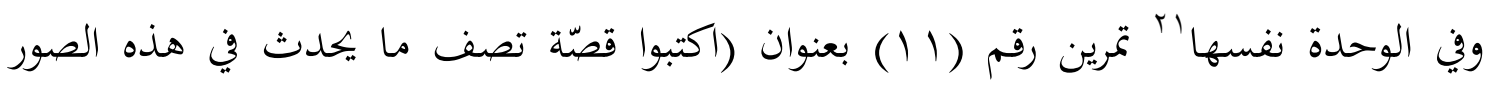

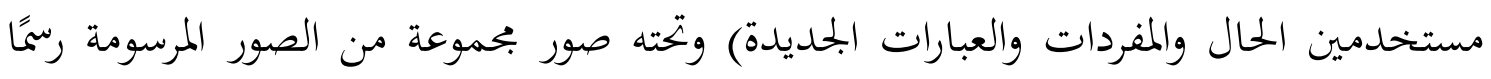

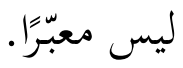

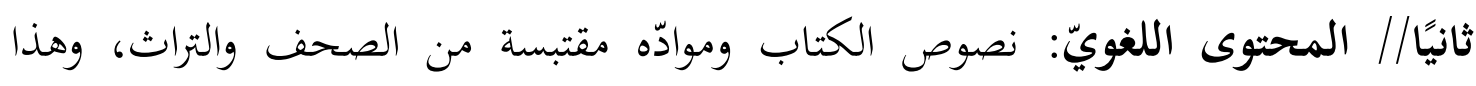

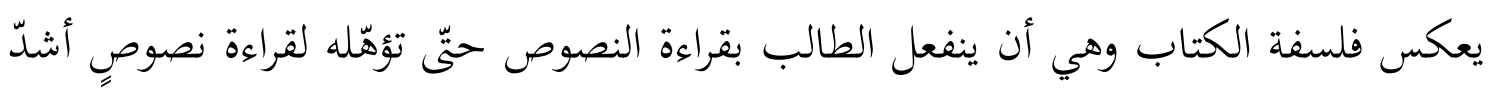

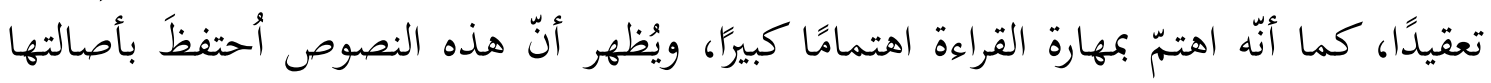

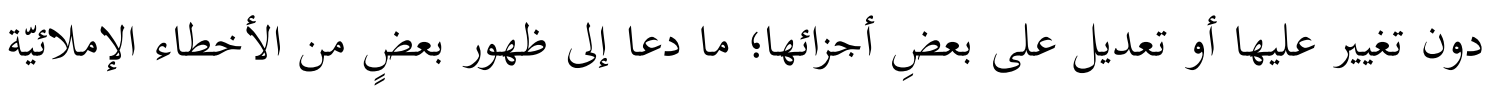

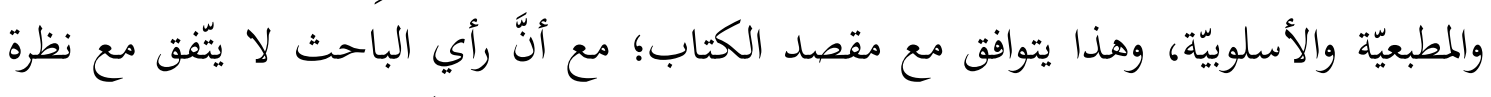

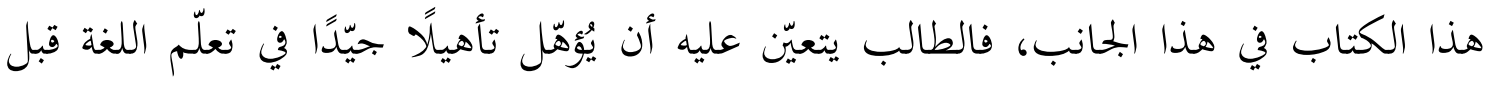

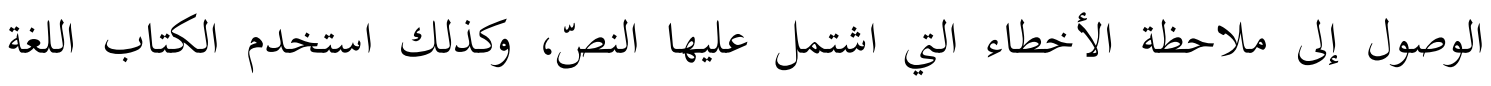

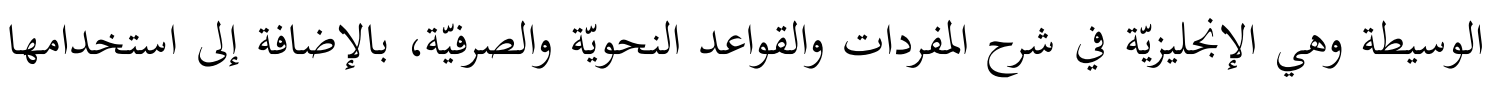

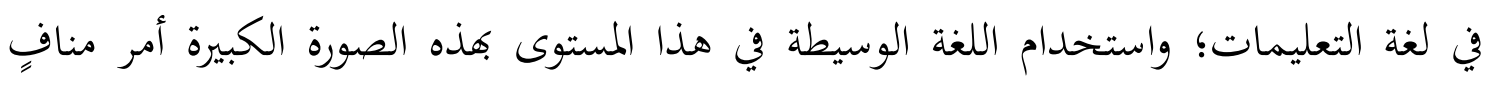

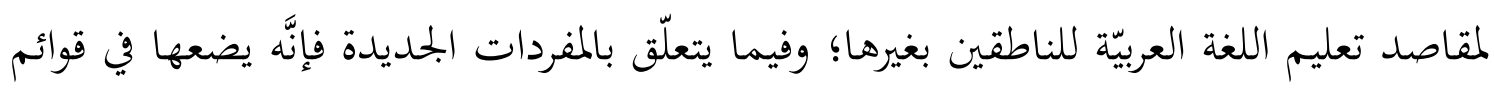

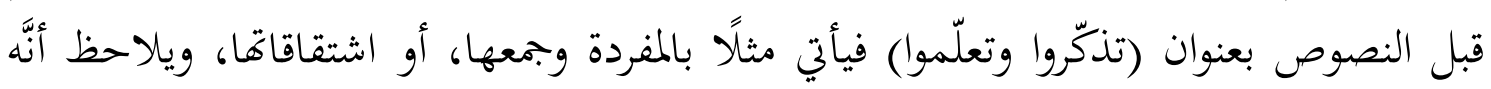

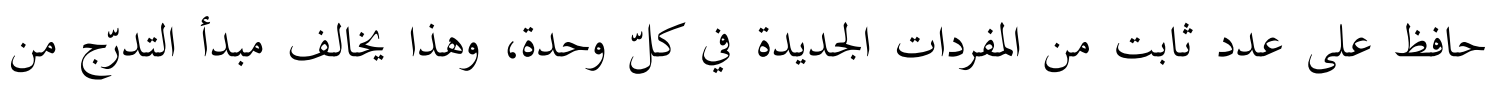

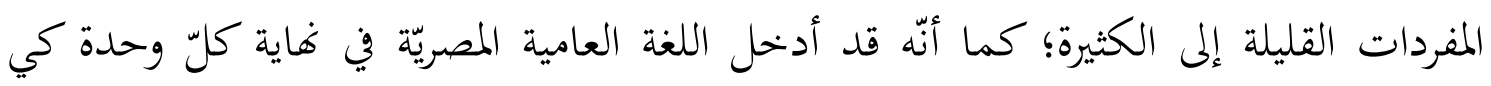

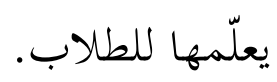

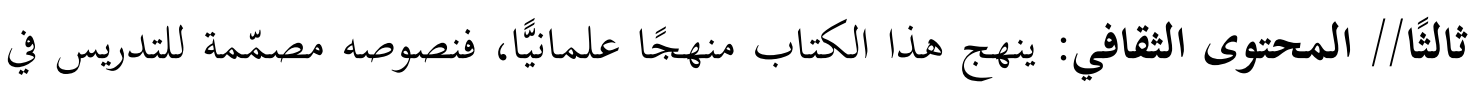

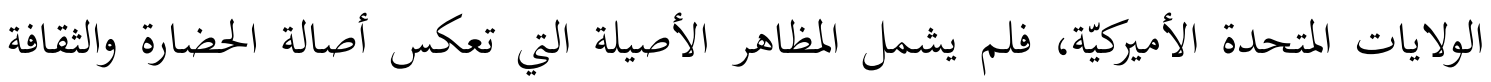

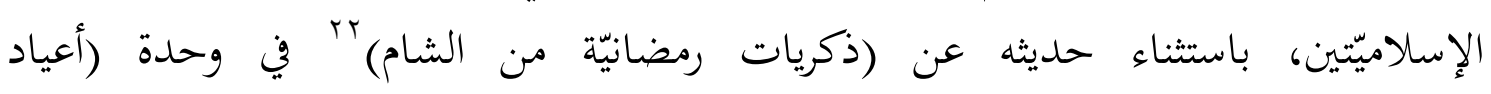

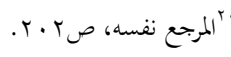

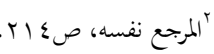

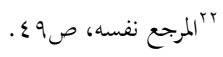




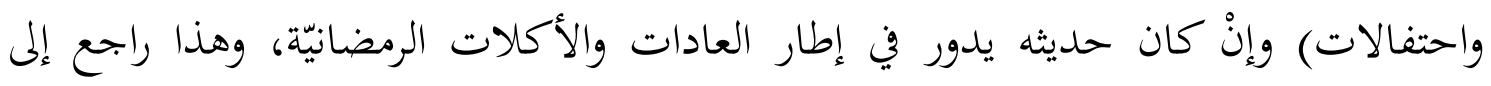

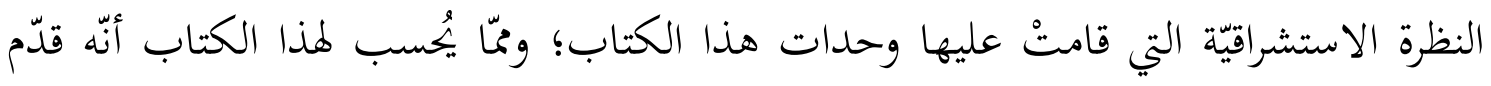

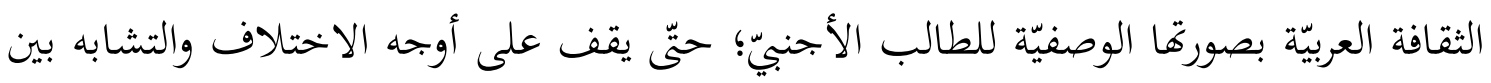

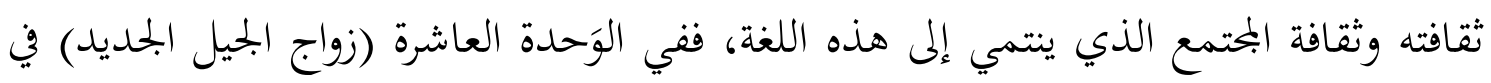

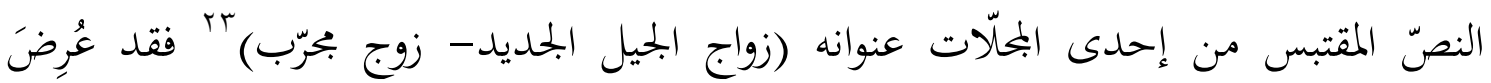

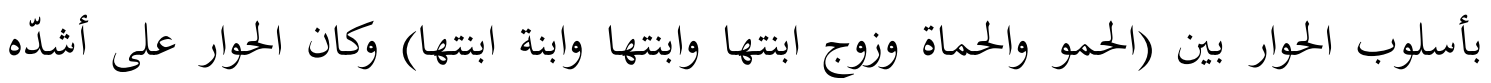

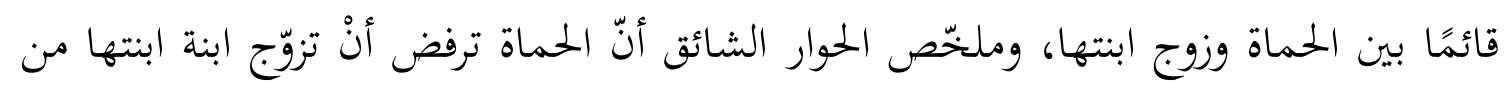

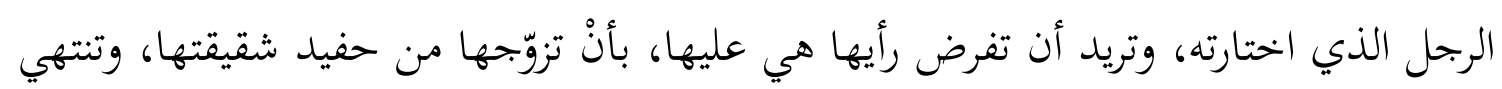

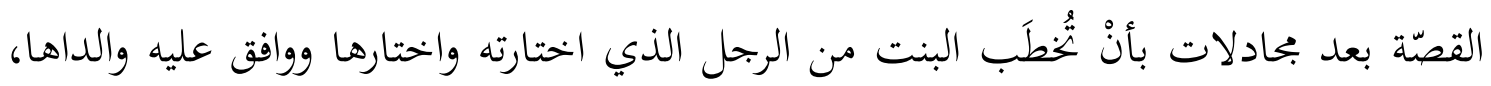

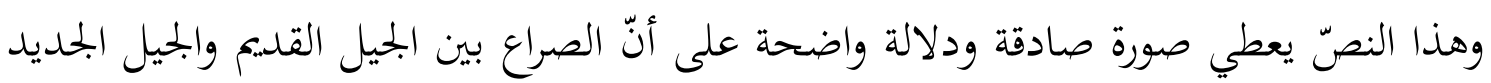

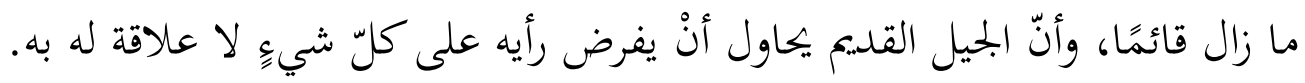

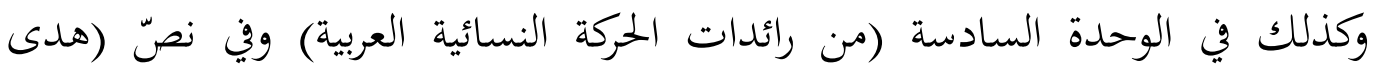

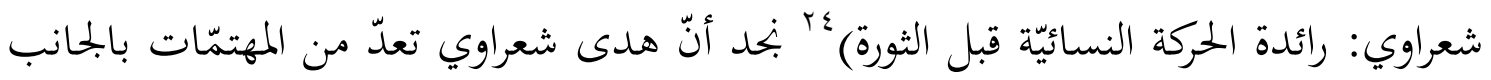

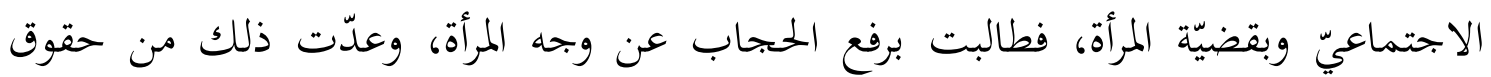

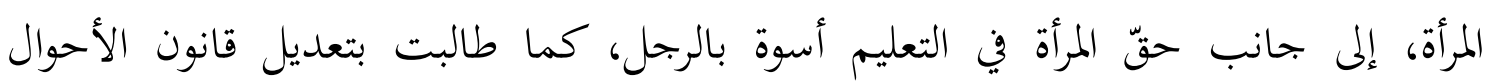

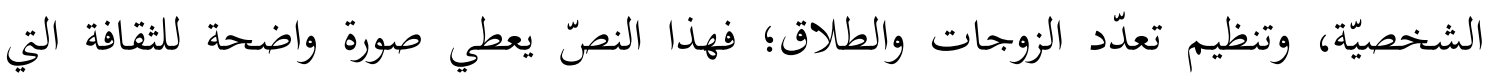

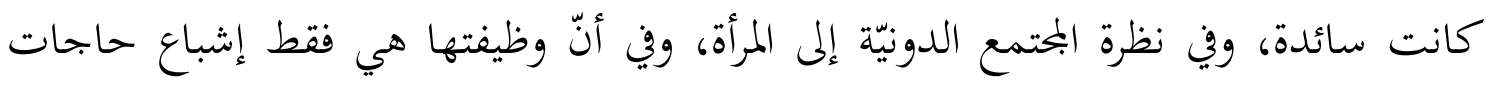
الرجل وجعلها وعاءَه. رابعًا// طريقة عرض المادّة: قدّمت الموادّ التعليميّة في صورة وحدات دراتِ دريّة رئيسة، تحتوي

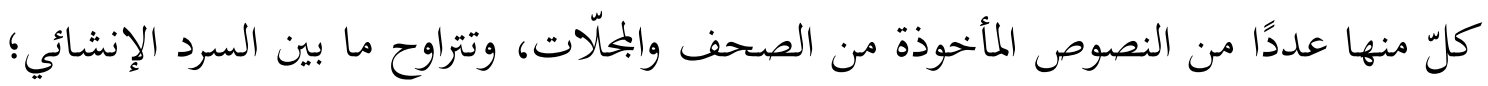

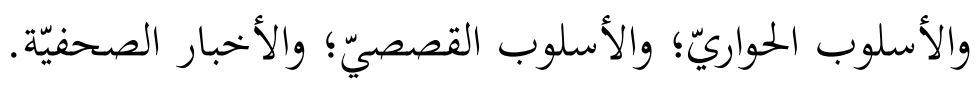

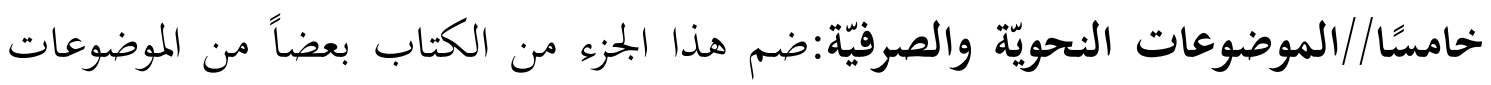

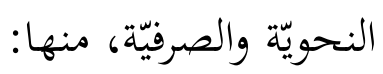

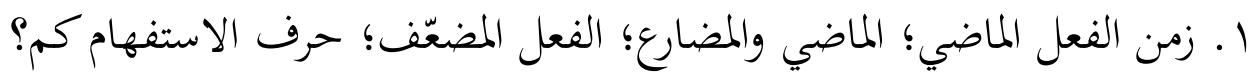
r. اسم الفاعل واسم المفعول؛ سقوط إنّ في الإضافة. 
ب. كان وأخواتا؛ الإضافة؛ مراجعة وتوسيع؛ الفعل المبنيّ للمجهول.

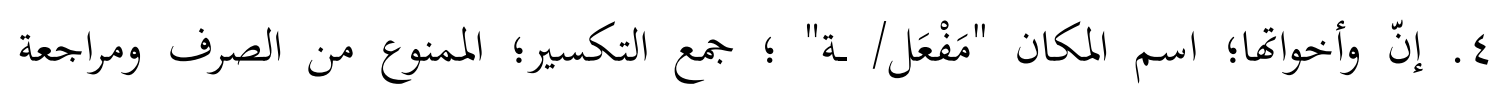

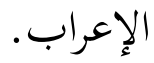

هـ الإضافة غير الحقيقيّة؛ "أفعل" التفضيل ووزن "فُعلى"؛ التمييز.

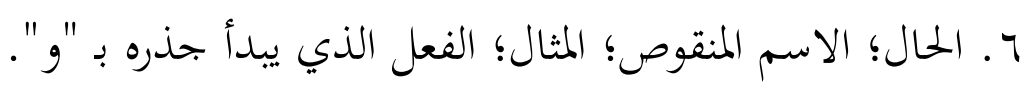

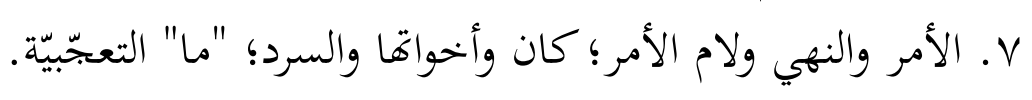

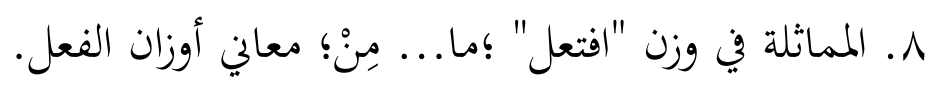

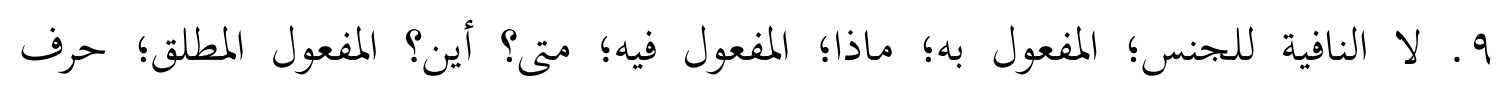

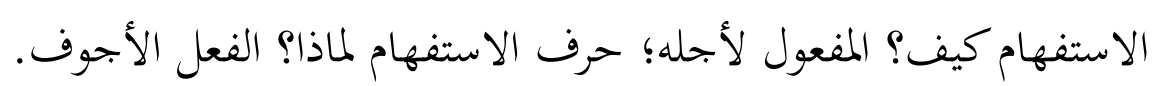

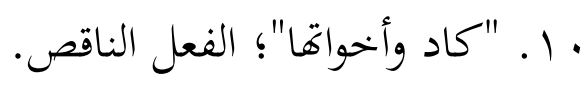

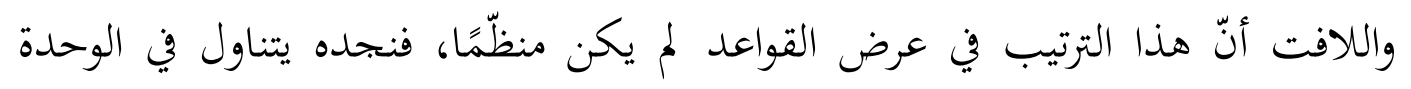

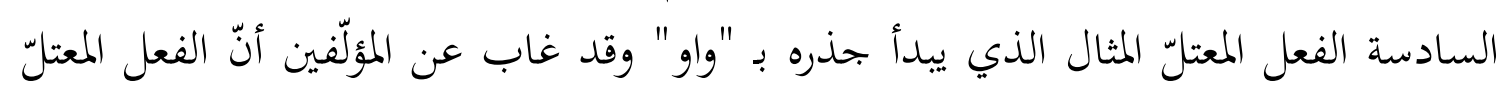

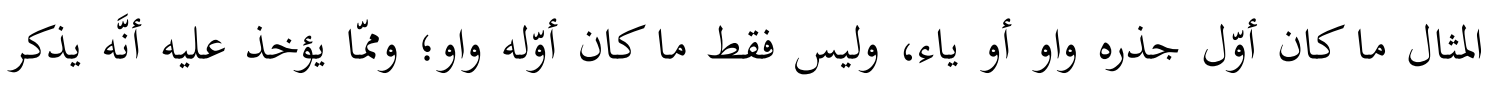

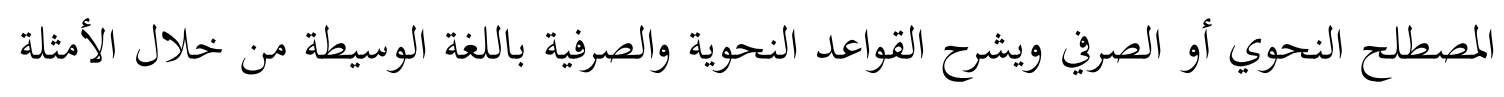

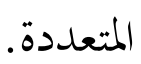

سادسًا / ملحوظات عامّة:

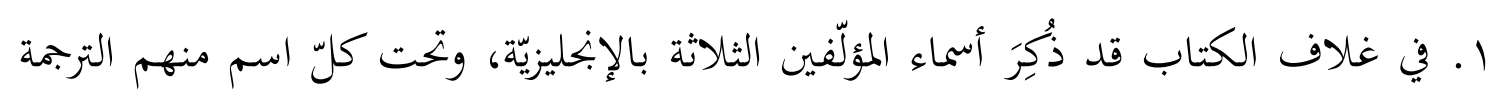

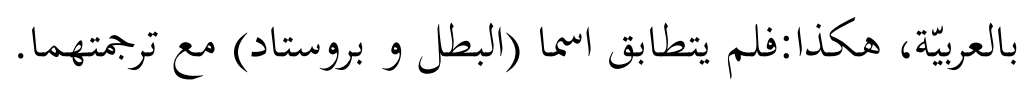

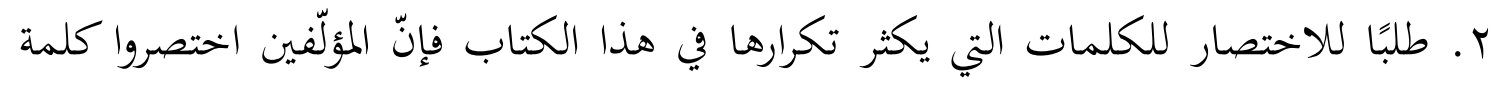

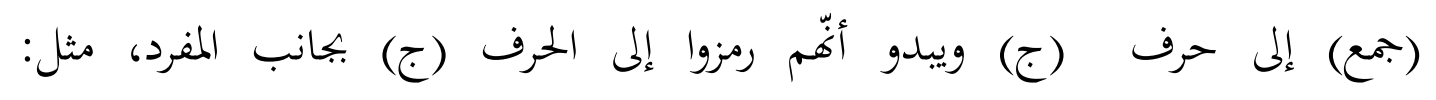

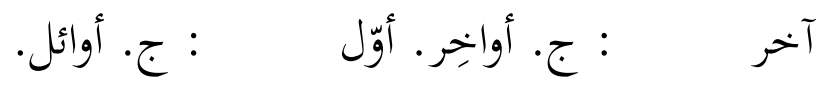

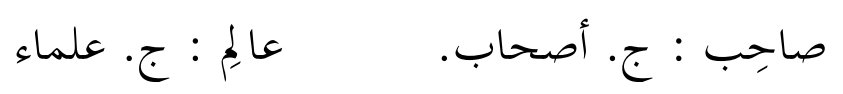

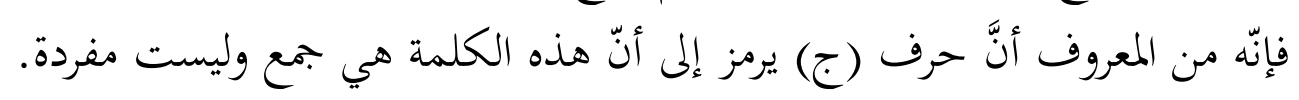

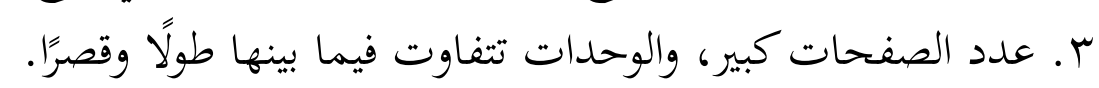

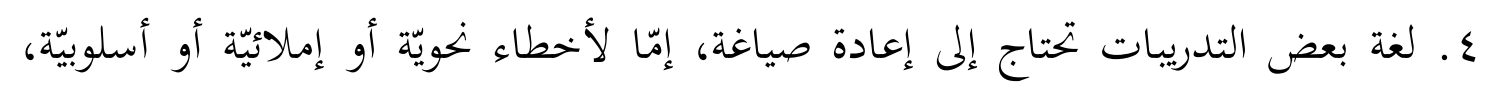

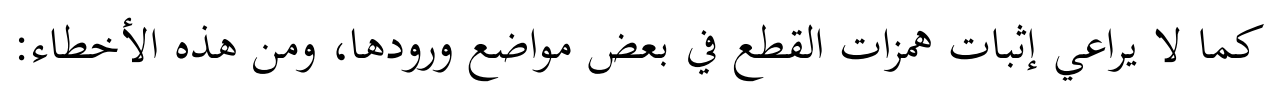




$$
\begin{aligned}
& \text { أ. هو ابو عبد الله محمد اللواتي مُ ك. }
\end{aligned}
$$

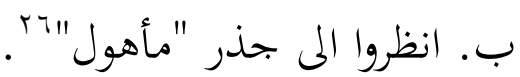

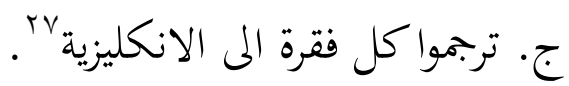

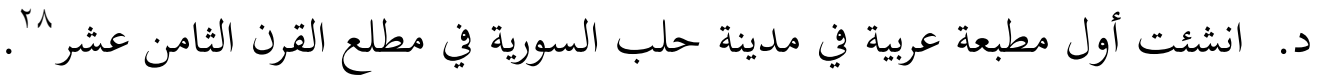

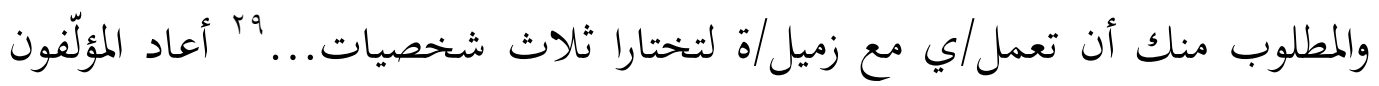

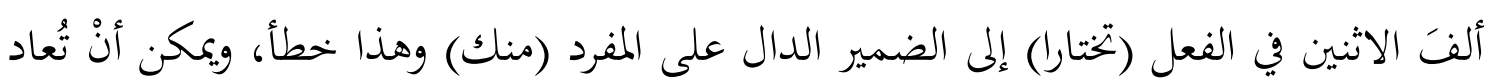

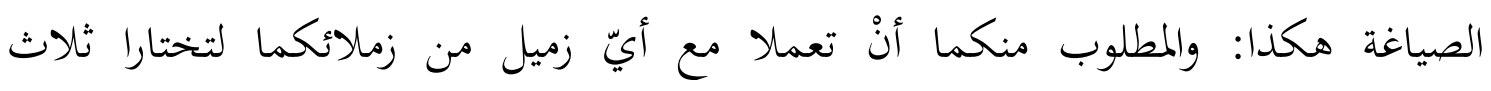

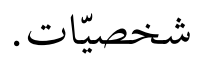

هـ هل تفضّلون الدراسة في جامعة كبيرة أو صغيرة ولماذا؟`مَفإنّ حرف الاستفهام (هل) تدخل عليه (أم) المراد بها التعيين، وليس (أو) المراد بها التخيير.

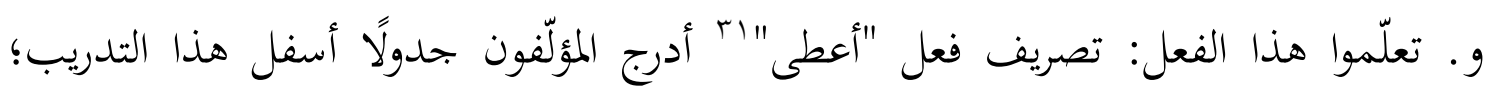

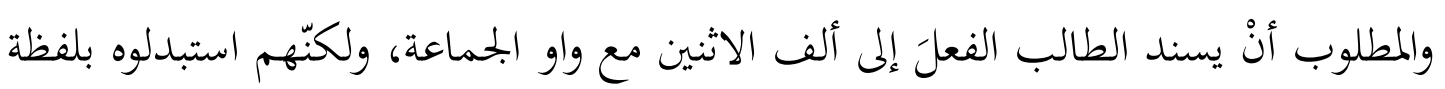

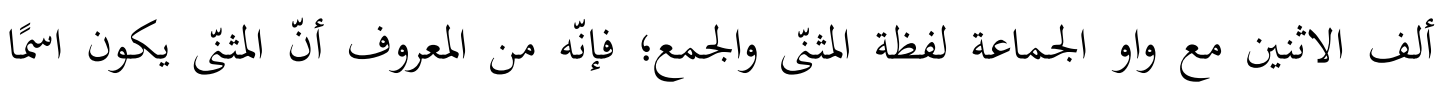
وكذلك الجمع، وهم استعملوا هذه الألفاظ للدلالة على الفعل.

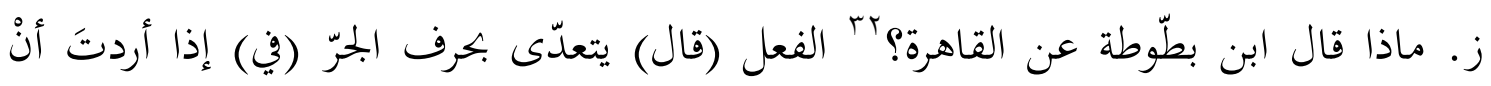

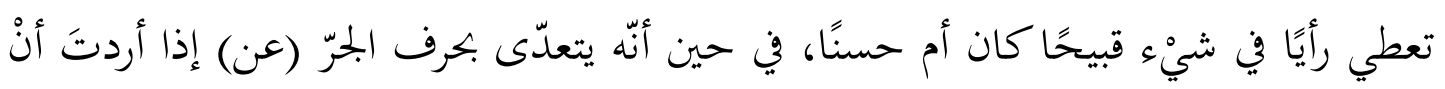

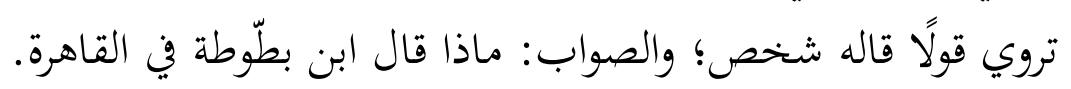

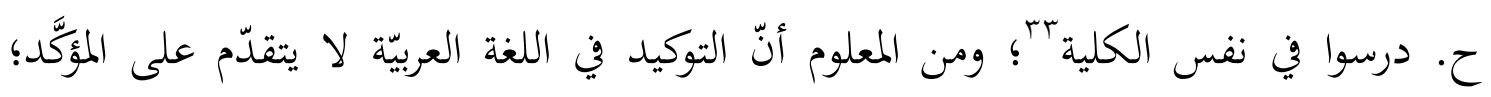
والصواب: درسوا في الكلية نفسِها.

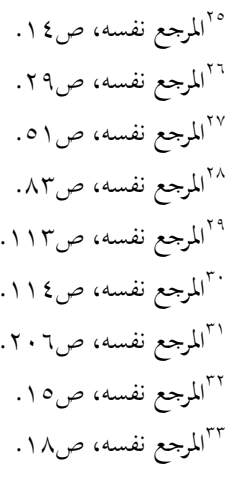




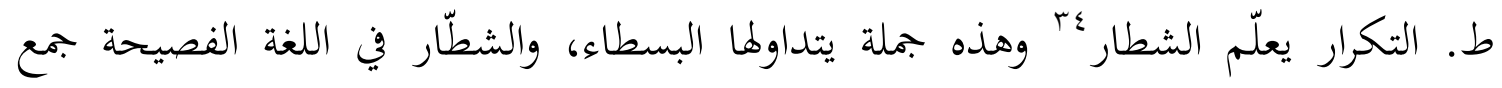

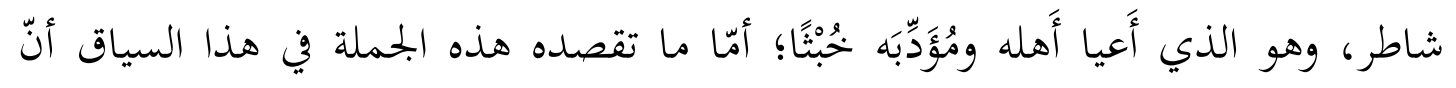
التكرار يعلّم الأذكياء والناهين، وفرق كبيرٌ بين المعنيين.

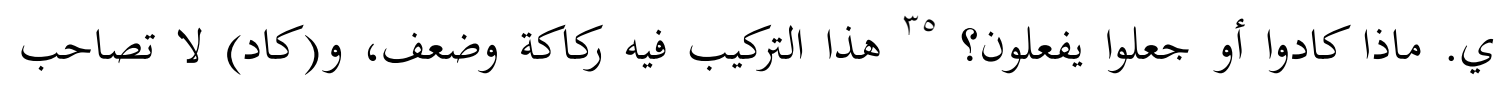
(ماذا) لأنّ (كاد) من أفعال المقاربة، وهي أفعال ناقصة.

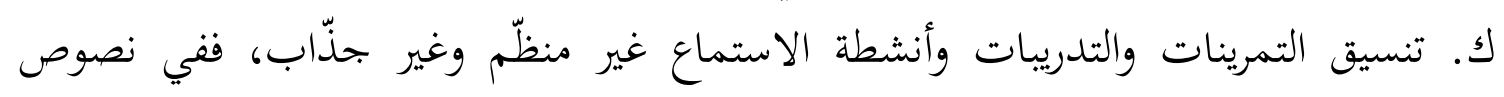

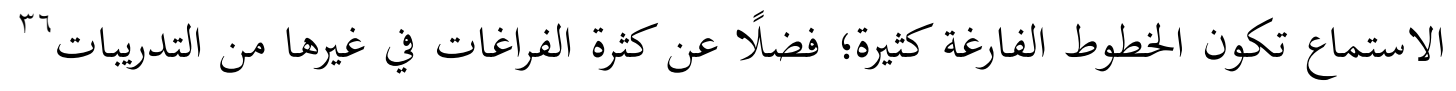

ه. بحح هذا الكتاب في إعطاء المعلومات المتنوّعة العامّة، وفي نصوصه المختلفة، وين شرح

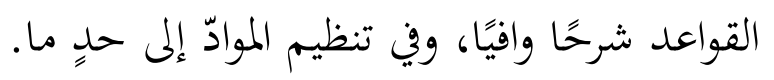

ت*** تحليل بيانات الكتاب الثاني العربية بين يديك.

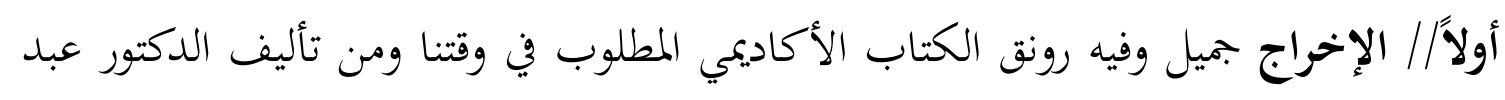

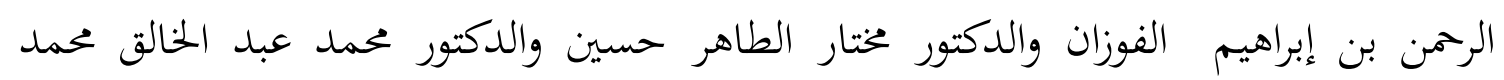

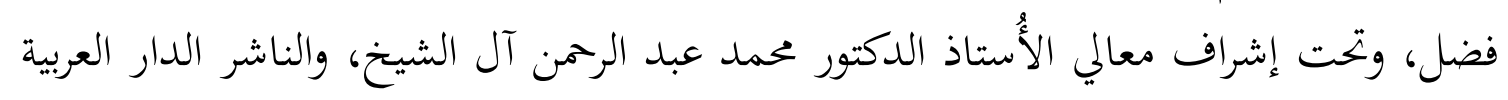

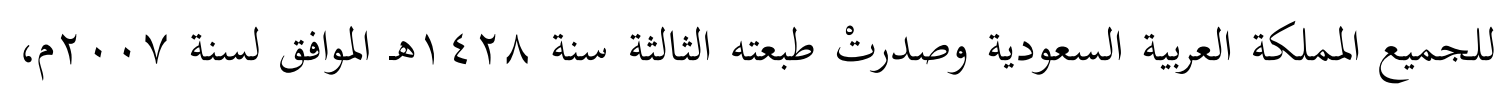

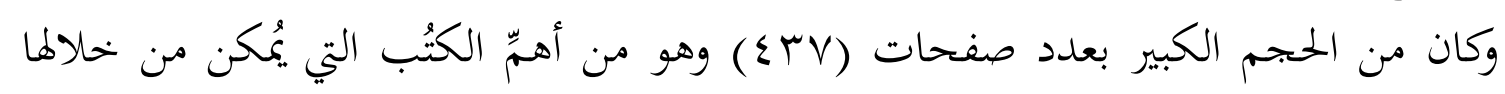

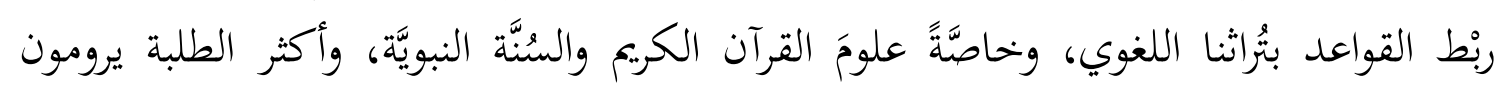

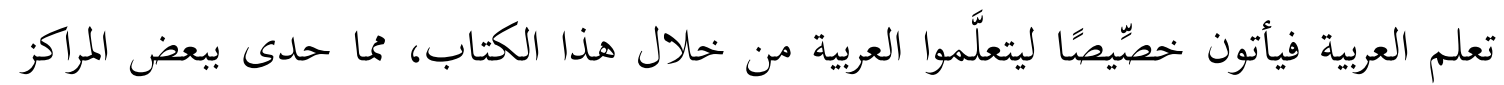

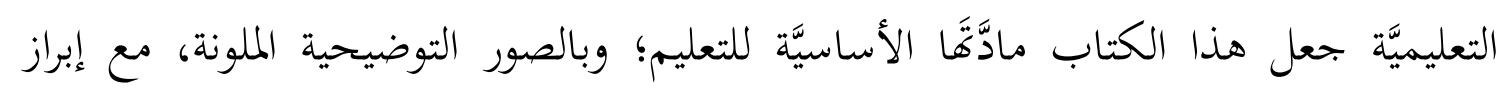

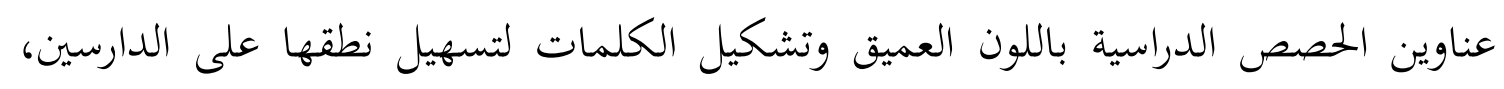

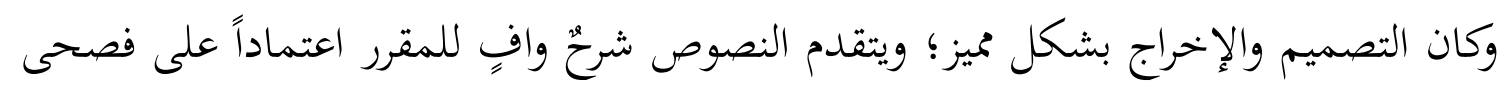

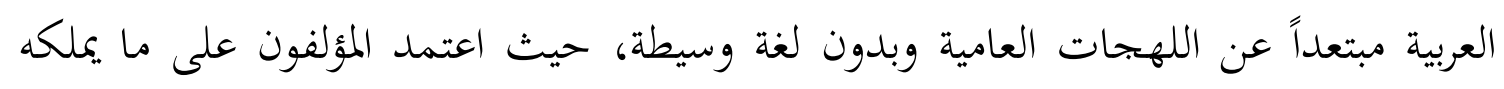

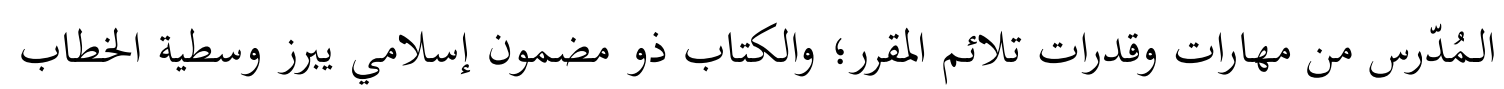
الديني ذا الطابع التوجيهي الأخلاقي. 
ثانياً// المحتوي اللغوي: فقد صدر بفصحى العربية وموازنة الكتاب قياسية وجلية في دروسه

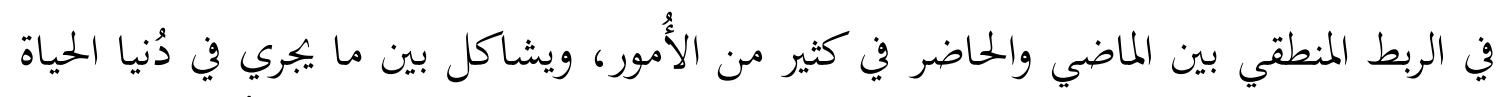

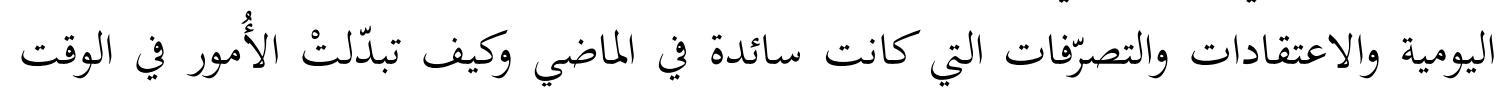

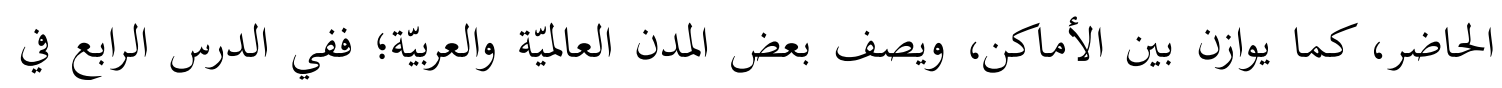

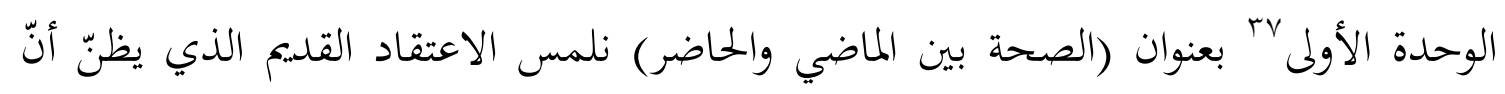

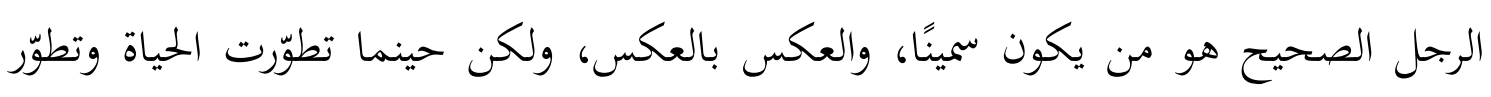

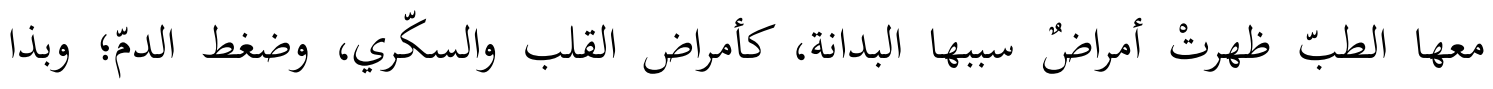

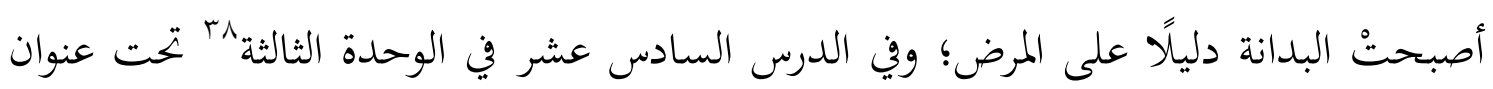

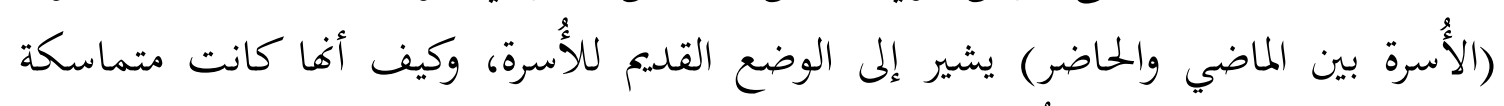

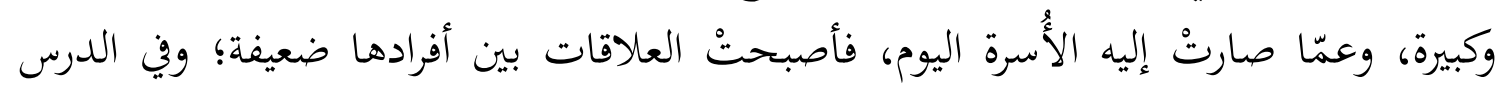

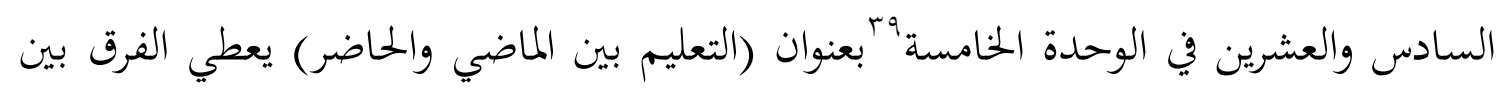

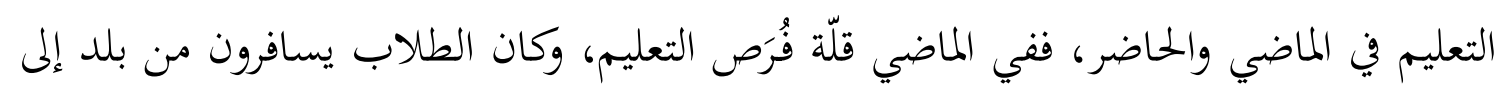

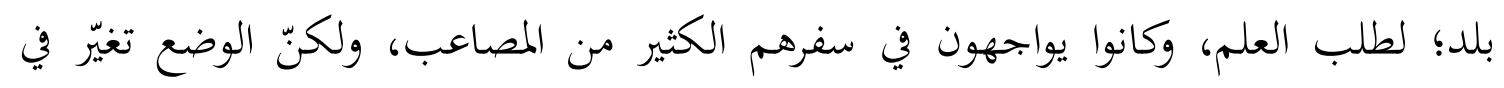

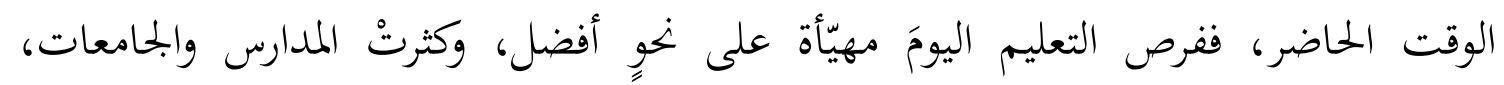

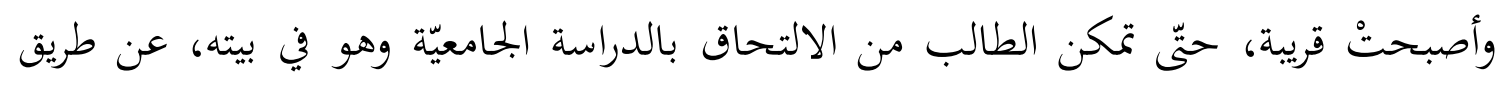

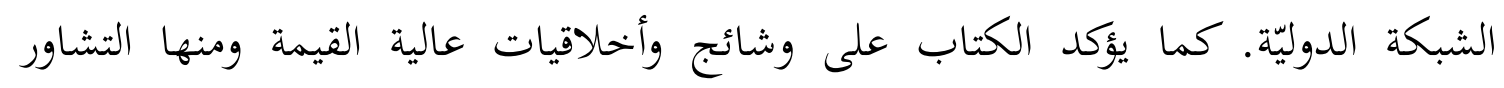

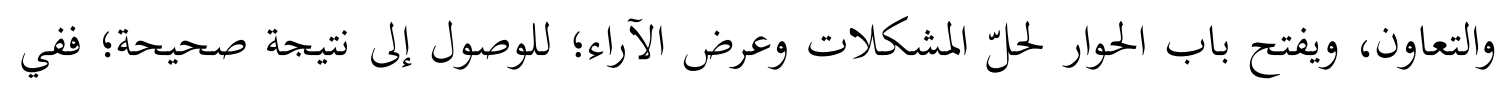

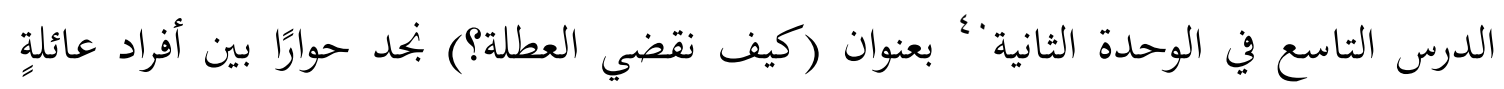

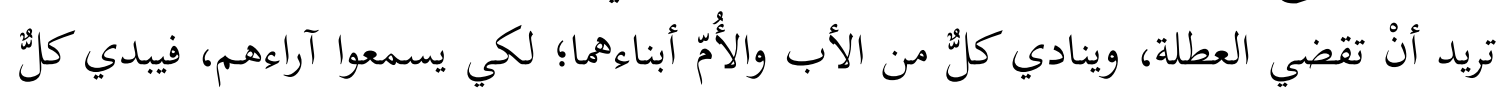

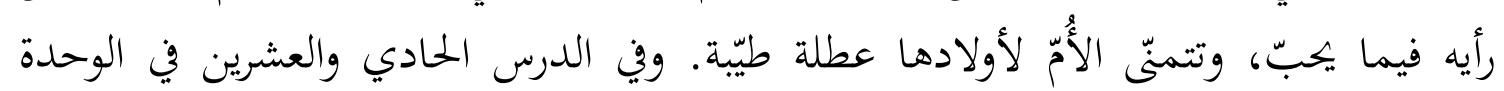

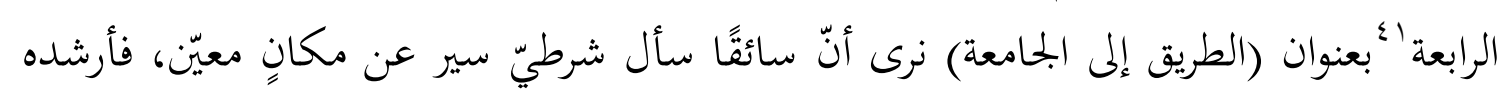

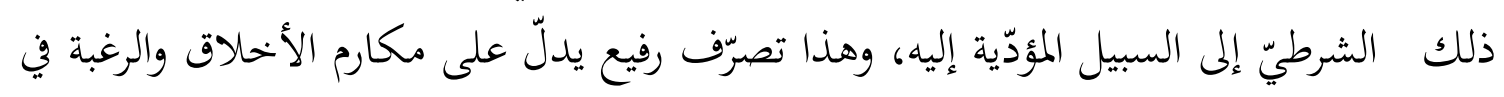

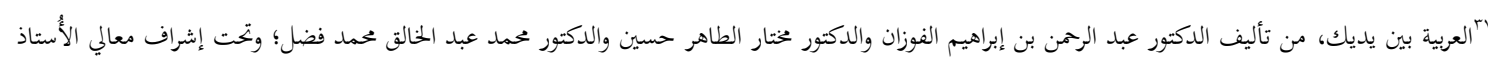

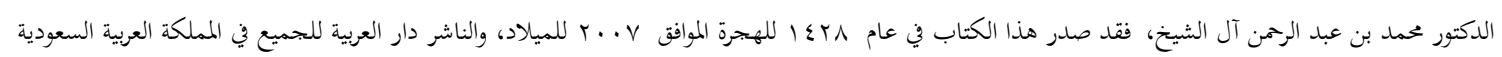
بطبعته الثالثة. . .

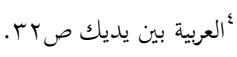

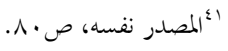


إرشاد الآخرين؛ وفي بحال حقوق المرأة يتيح الكتاب بحالاً للبنت في اختيار الزوج الذي ترى

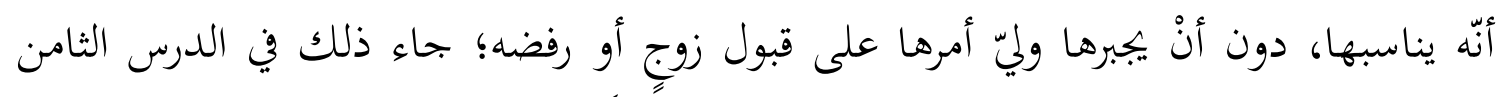

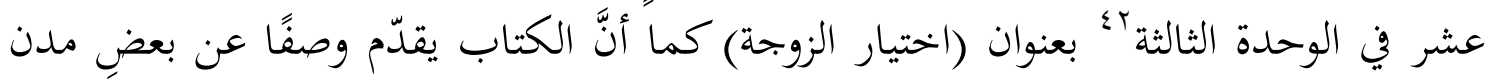
العالم الكبرى، مثل (طوكيو) في اليابان، و (نيويورك) في الولايات المتحدة الأميركيّة، و(القاهرة)

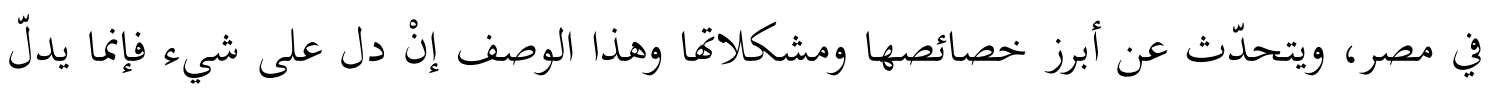

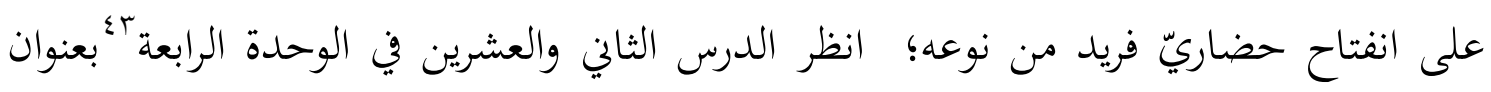

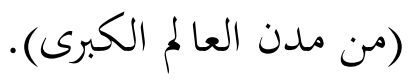

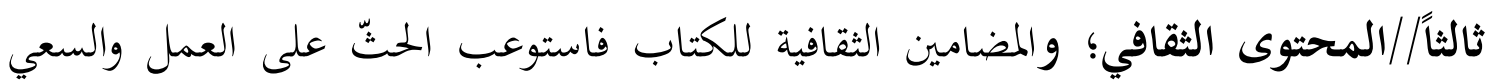

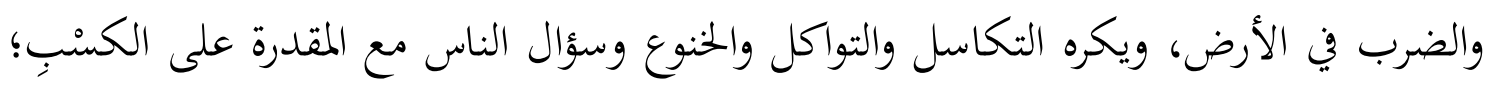

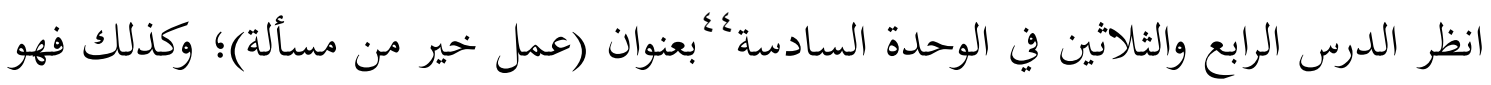

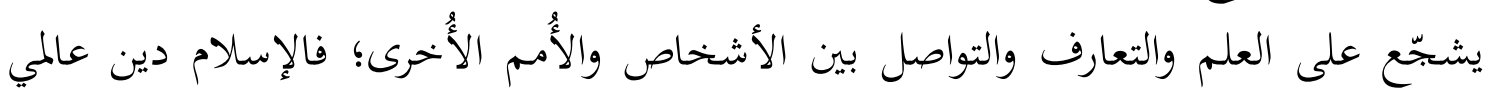

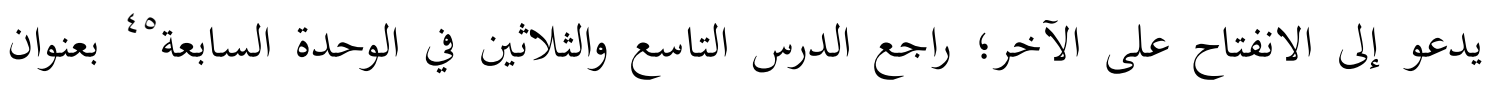

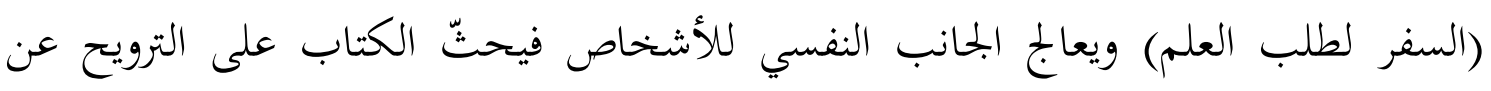

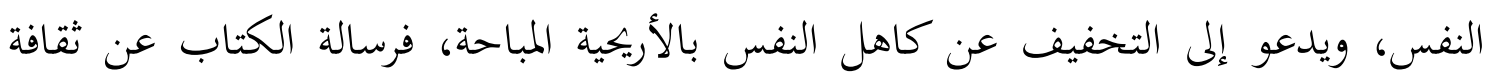

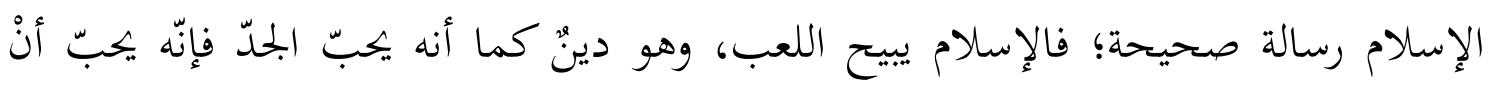

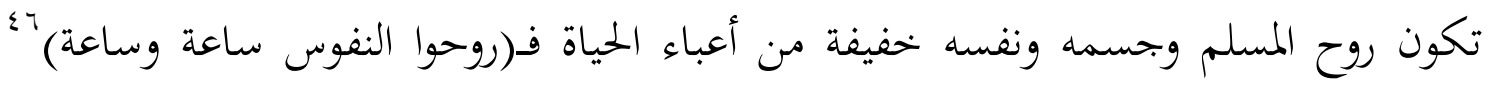

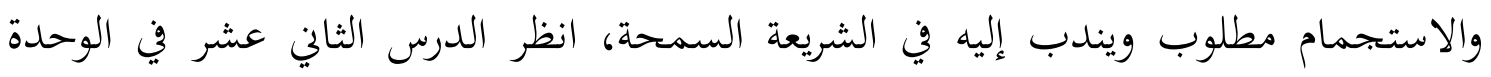

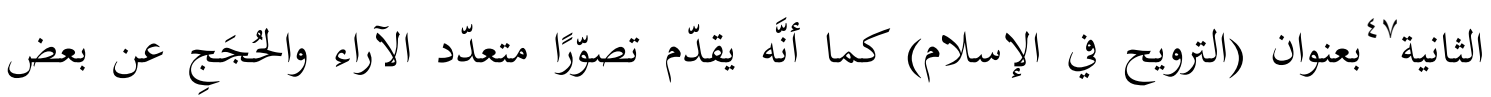

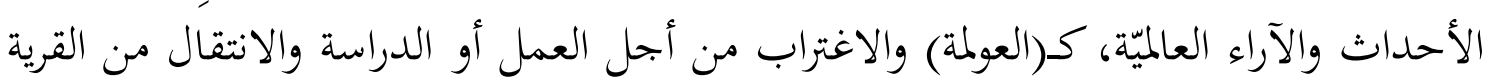

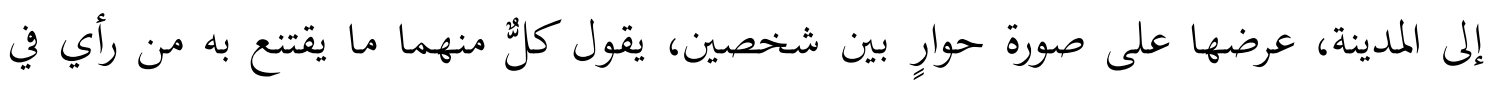

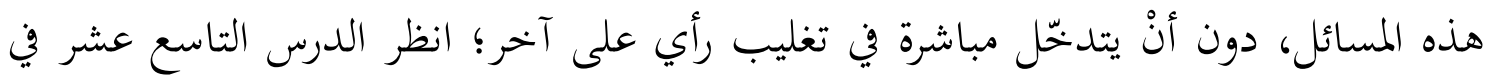

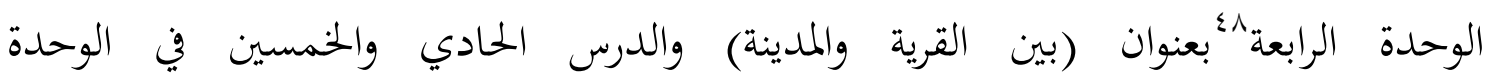

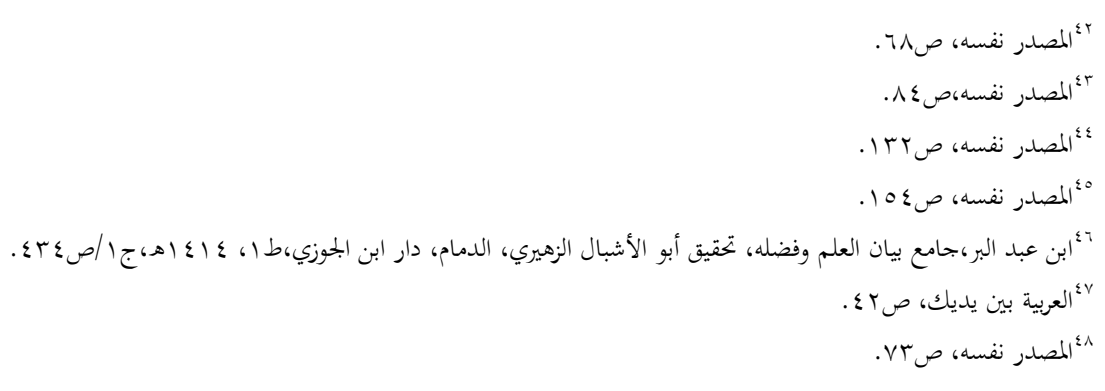


التاسعة 9ّعبنوان (ندوة عن العولمة)؛ ويشجّع الكتاب على أنْ نقرأ الإسلام كما كتبه الغربيّون

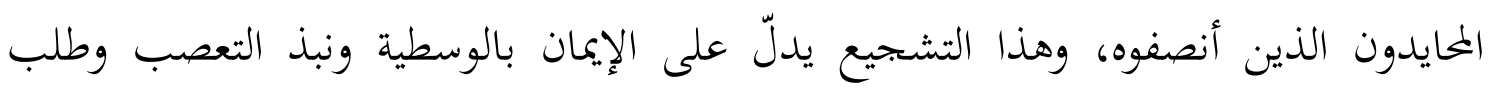

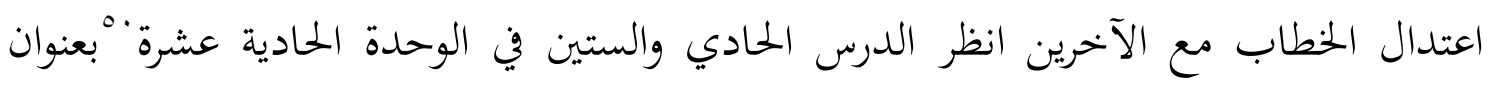

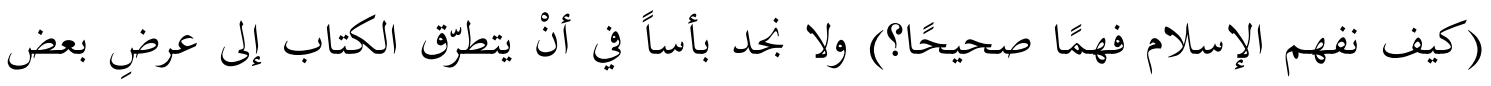

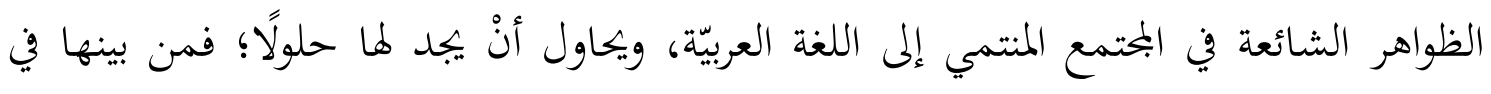

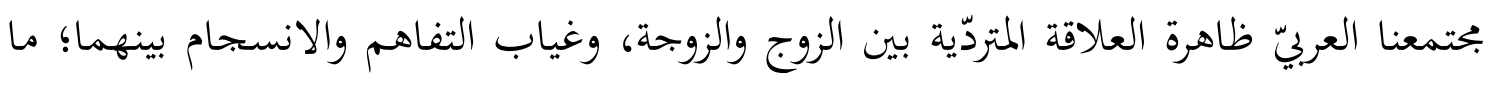

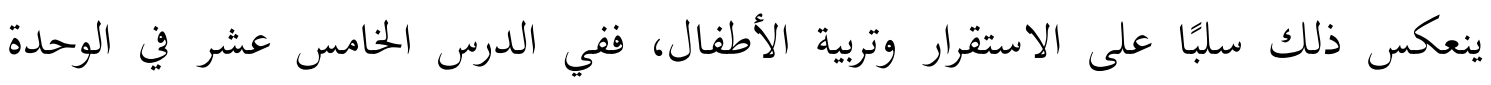

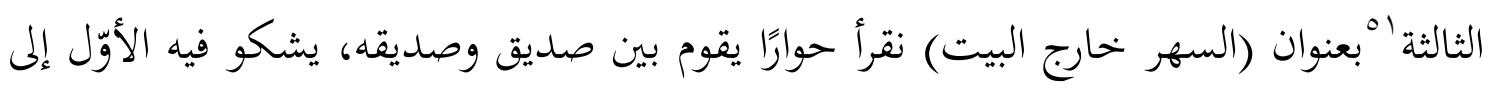

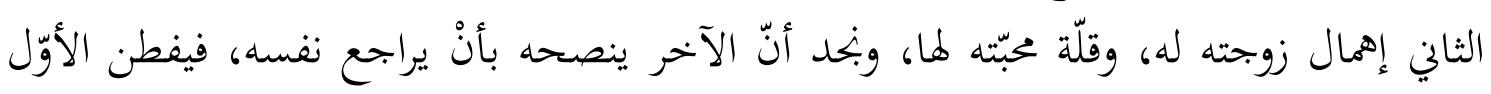

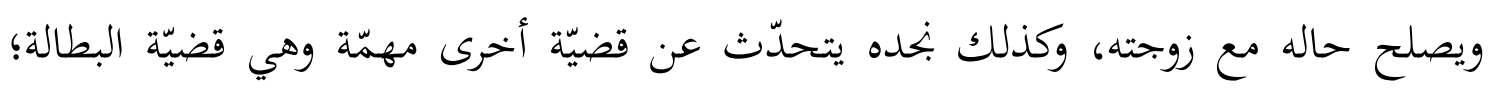

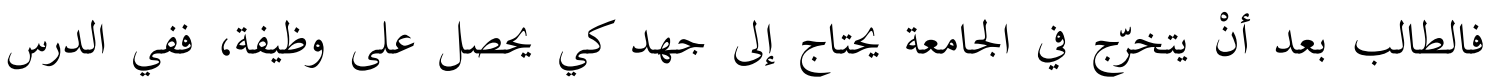

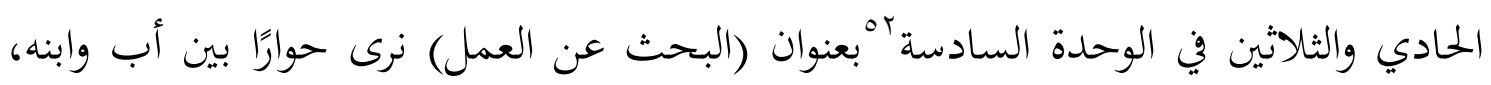

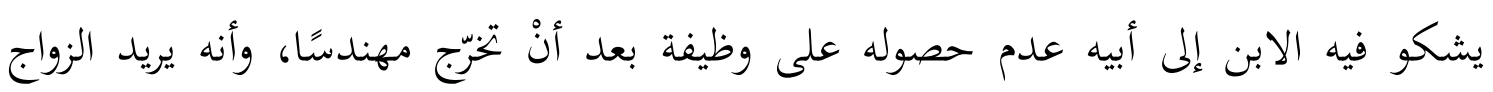

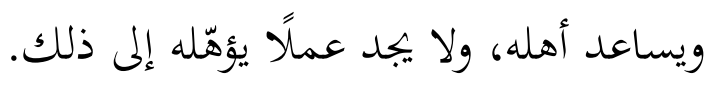

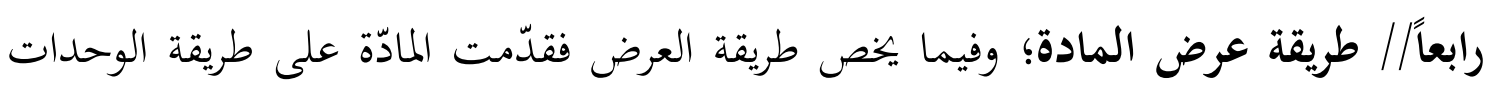

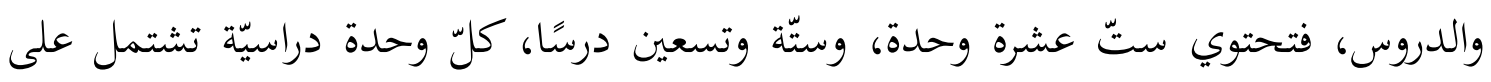

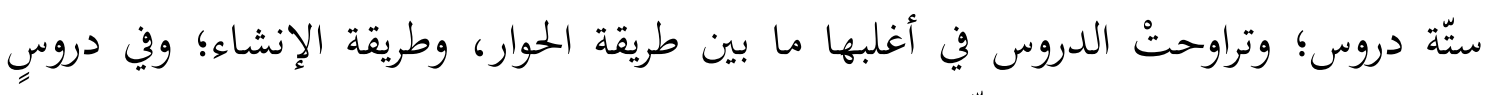

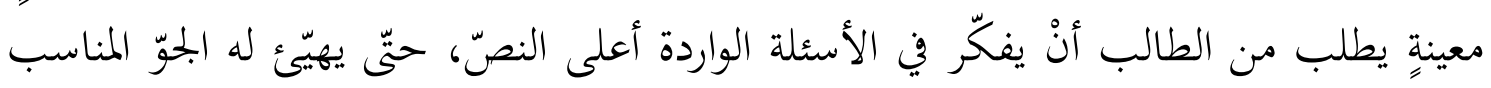
لمخول في ذلك النصّ.

خامساً// الموضوعات النحوية والصرفية: وعن إجراء التطبيقات العملية؛ فالحقيقة هناك

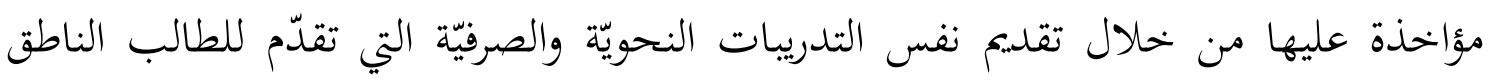

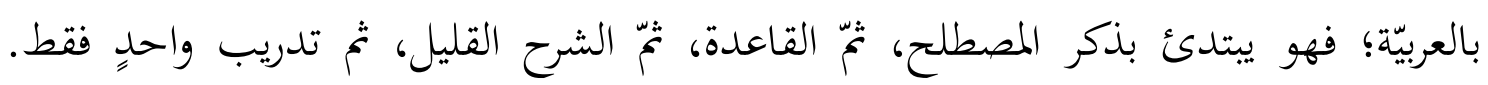

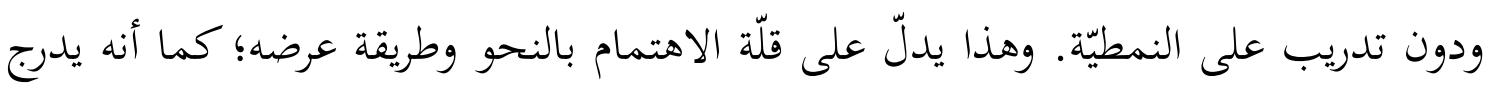

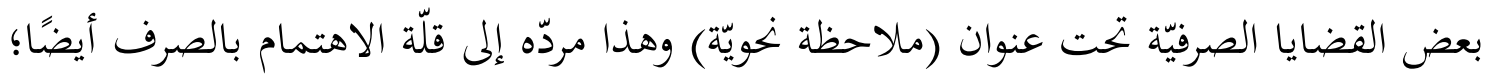

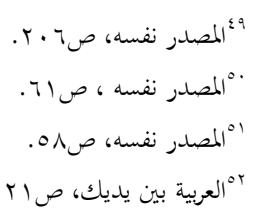




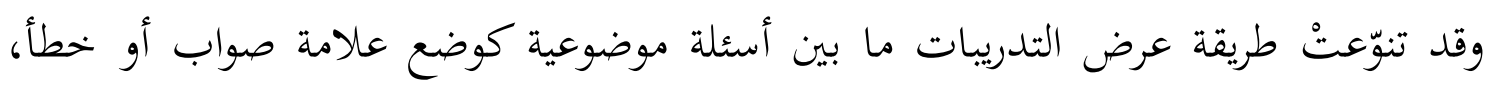

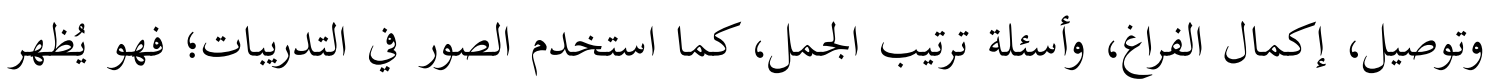

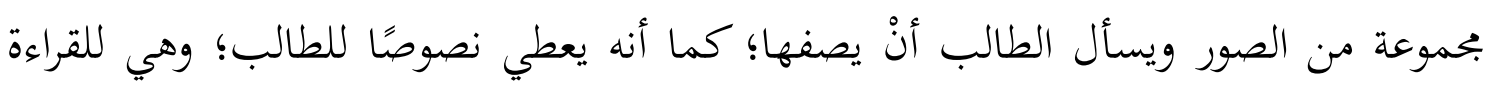

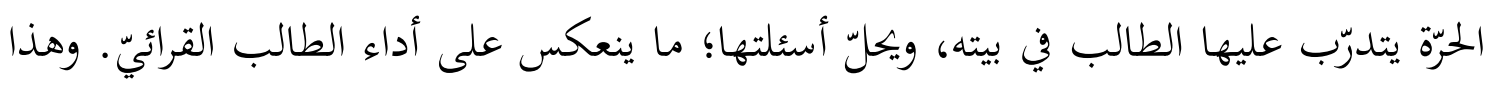

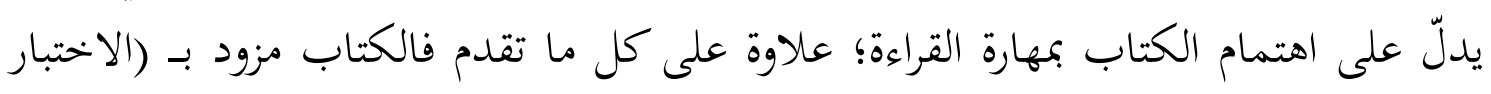

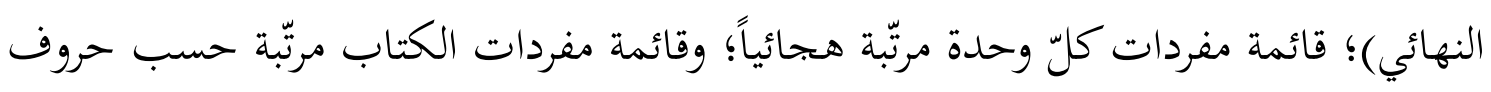

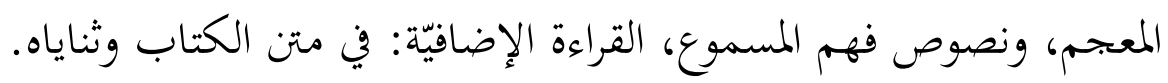

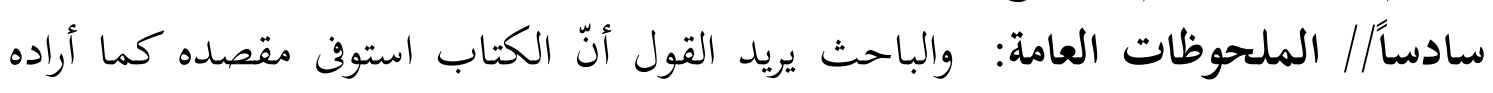

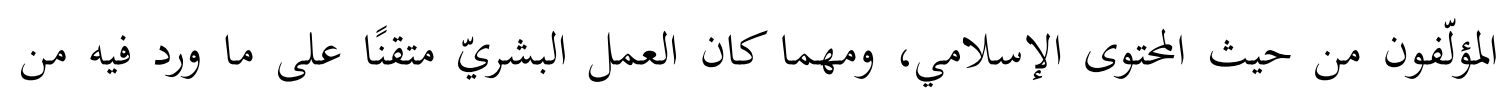

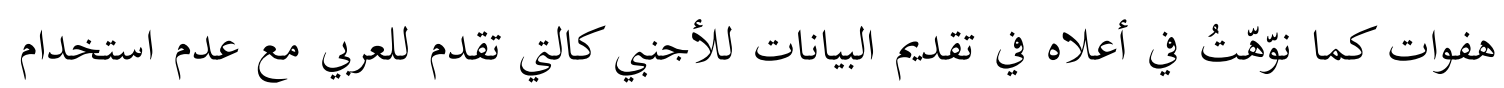

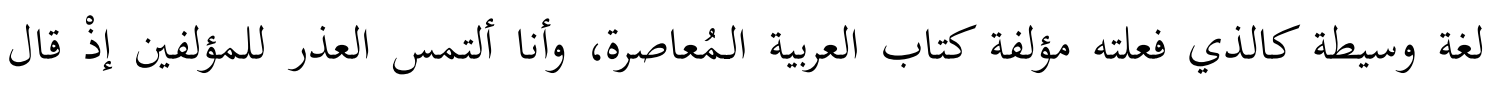

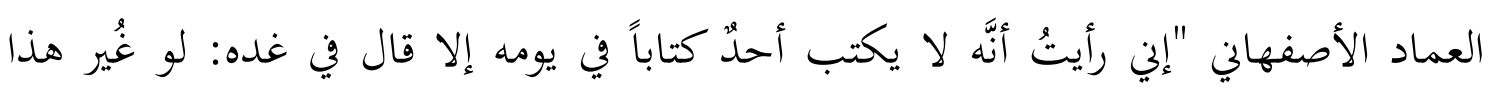

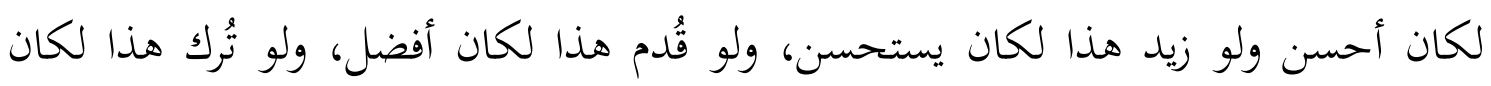

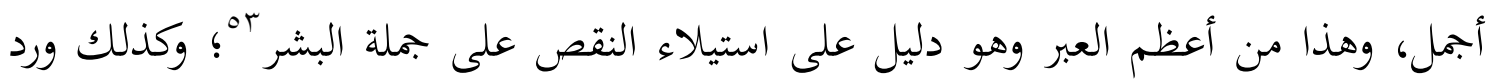

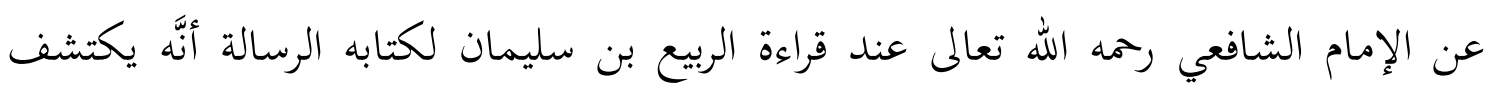

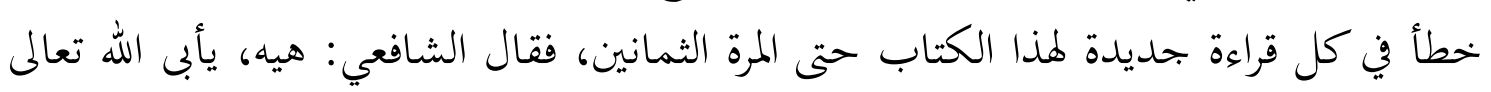

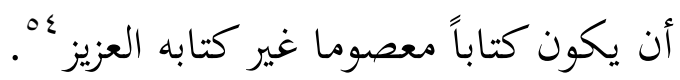

المبحث الثالث: الجوانب النظرية والنطبيقية اللازم توفرها في كتب تعليم العربية للناطقين بغيرها

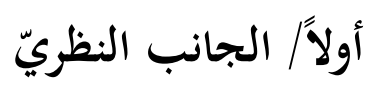
ا ـ كلّ الخبرات التي يمرّ بها الطلبة بصرف النظي النظر عن أين وكيف يتلقّاها.

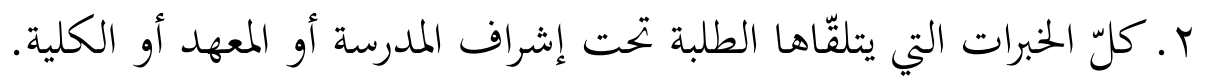




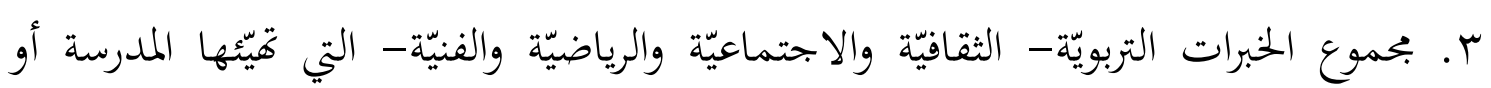

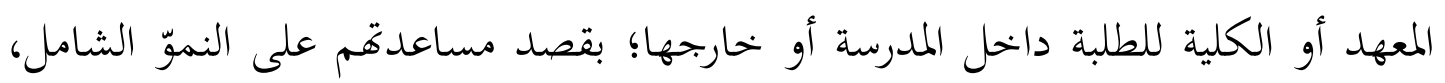

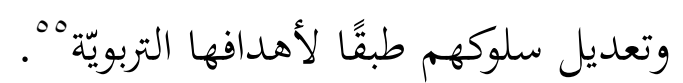

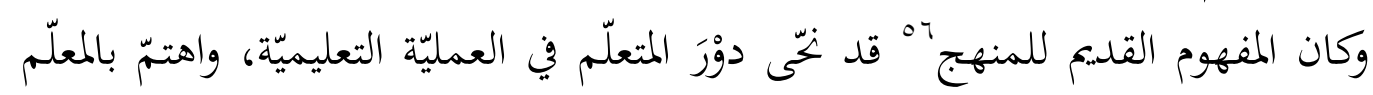

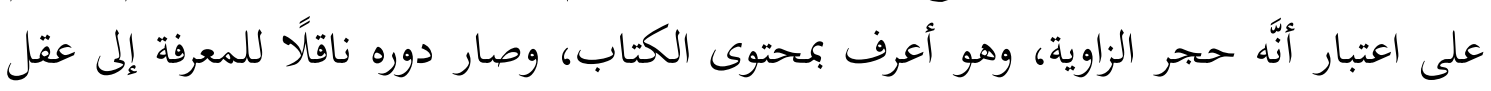

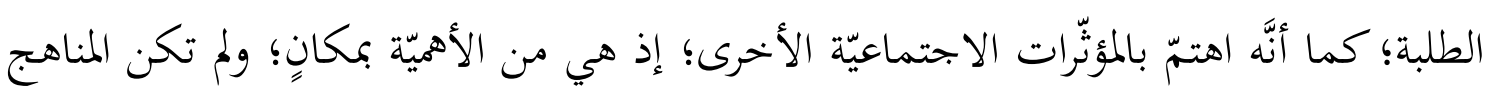

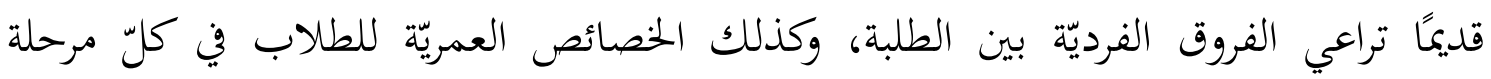

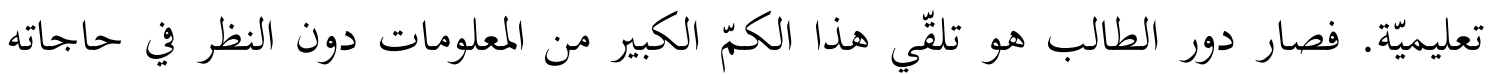
الأُخرى كالنفسيّة والاجتماعيّة.

ولمها تطوّرت الحياة في بحالاتها كافّة، أدّى هذا إلى إعادة النظر في مفهوم المناهج؛ لكي

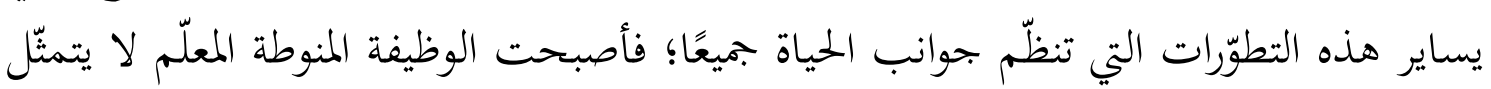

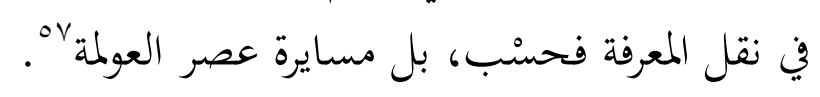

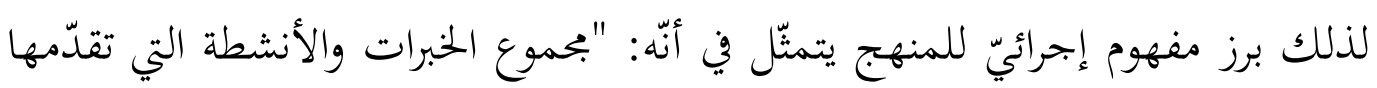

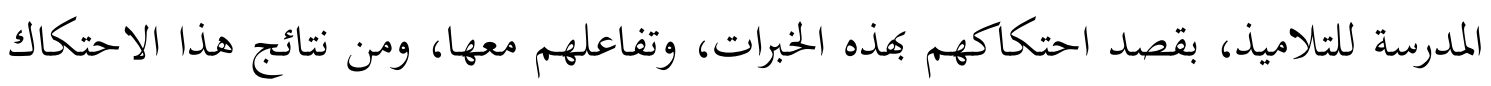

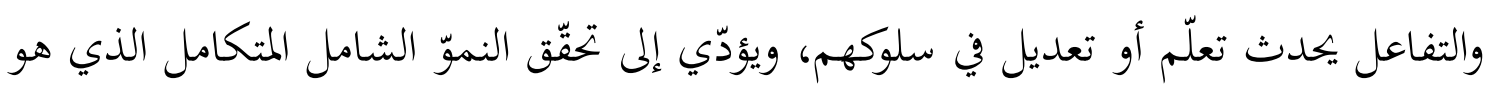

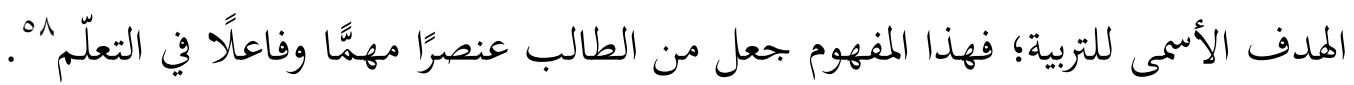

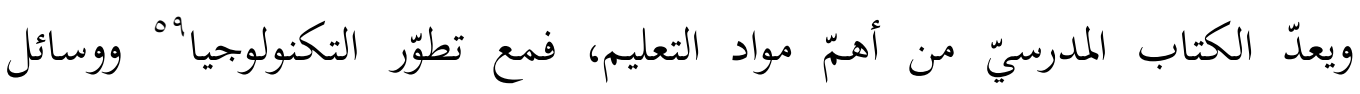

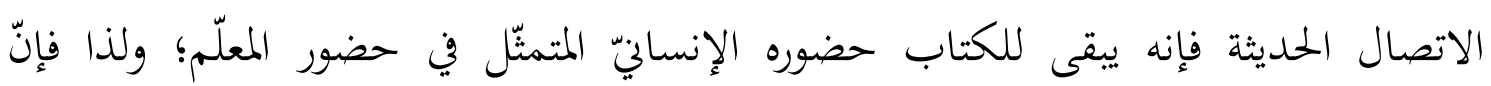

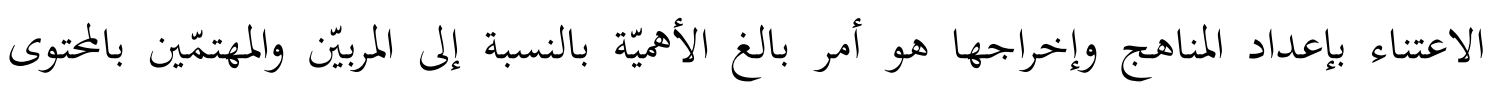
والمادة التعليميّة وطرق التدريس. باعداد امناهت واحراح. 
ولملا كان وجود المعلّم الماهر أمرًا ليس سهلًا فحين ذاك يتعاظم دور الكتاب؛ لأنَّه يحدّد

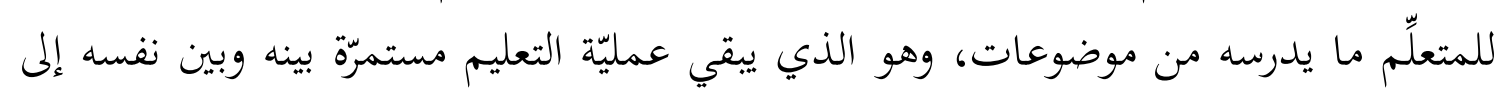

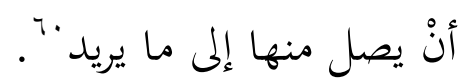

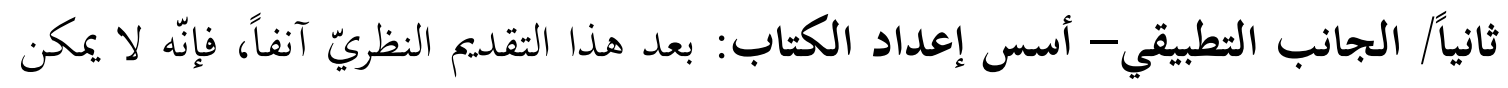

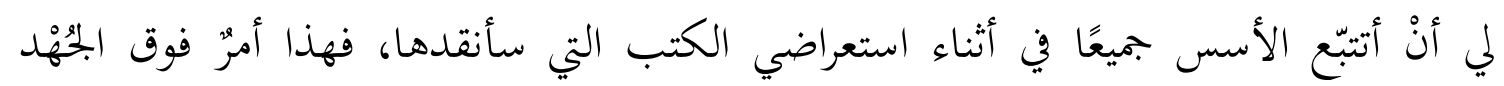

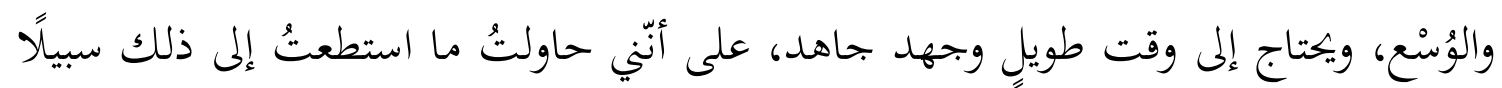

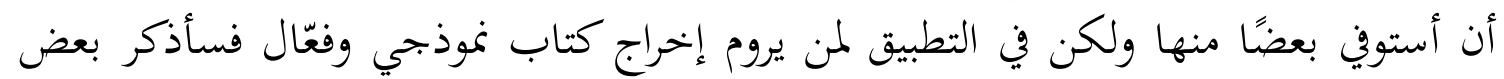

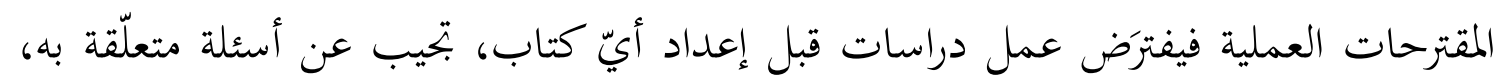
مثل:

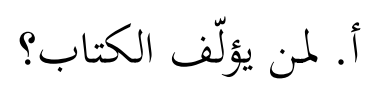

ب. ما المستوى اللغوي الذي يؤلّف له الكتاب؟ لهن

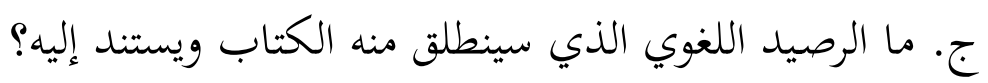

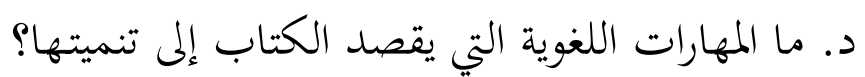

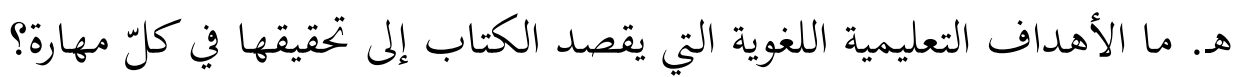

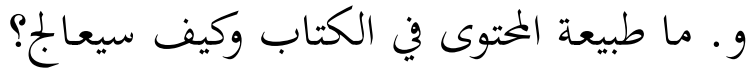

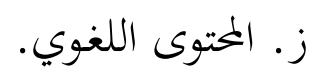
ح. المحتوى الثقافي. ك. كا شكل التناول التربوي لمتوى الكتاب؟ النعاب،

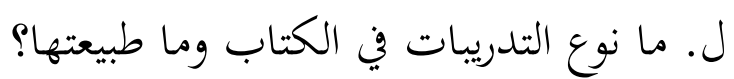

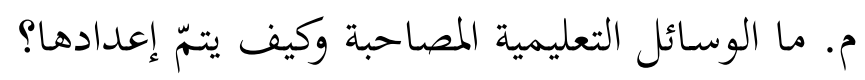
ن. ما شكل الكتاب، وما حجمه، وما قواعد إخراجه؟

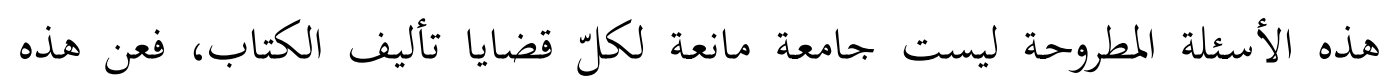

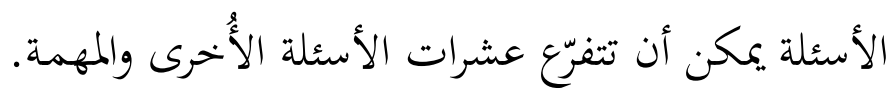

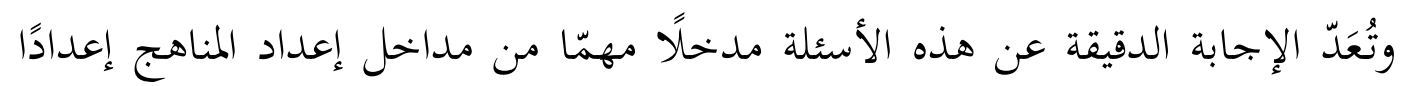

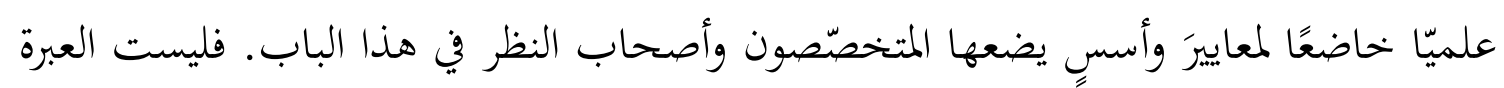


في كمّ الكتب ومدى وفرقا، بل في قدرقا على إفادة الطالب الأجنبيّ منها إفادة تتيح له أهما

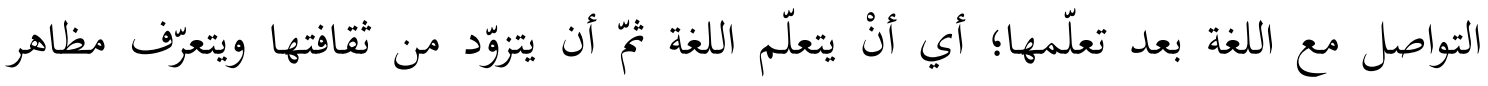
الحضارة المرتبطة بها، شأنه شأن أيّ ناطق بها.

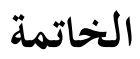

أولاً/ النتائج العلمية. ا ـ الفرق بين مناهج تعليم اللغة العربية للناطقين بها وللناطقين بغيرها: وهنا يبرز سؤال

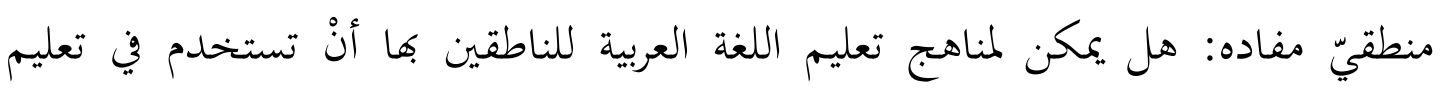

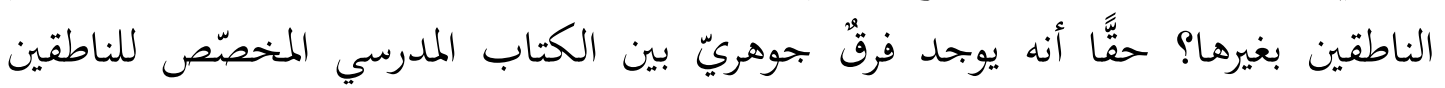

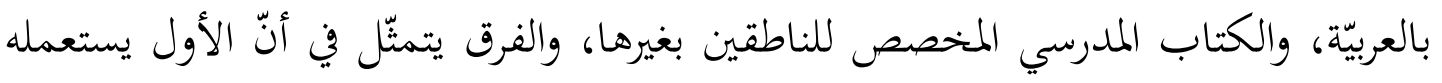

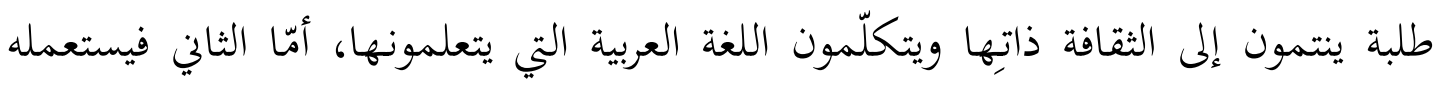

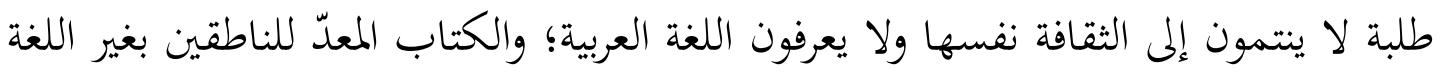

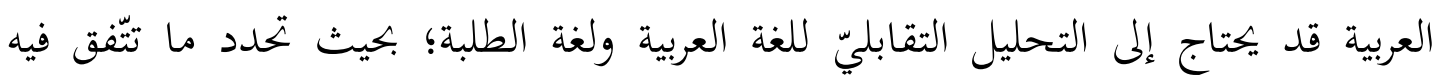

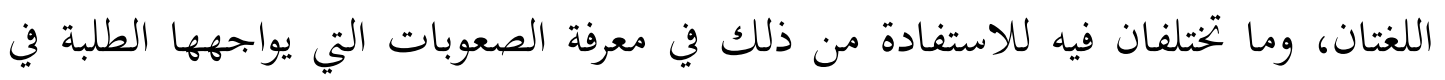

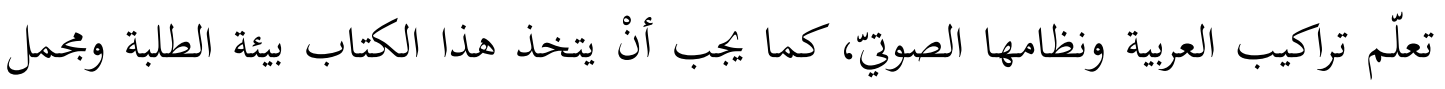

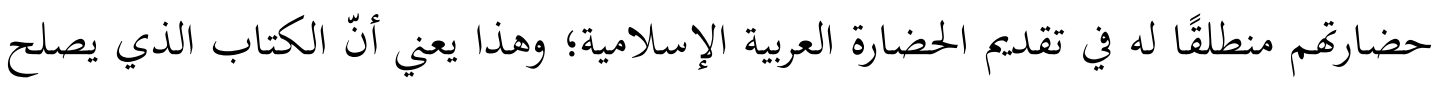

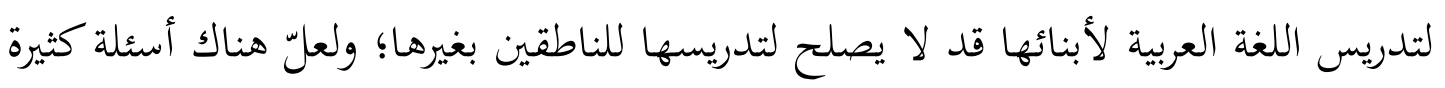

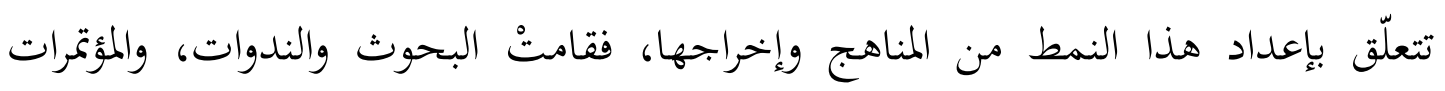
لوأجل ذلك. r. اللغة والثقافة والدين في مناهج تعليم اللغة العربية للناطقين بغيرها: إنّ كثيرًا من مناهج

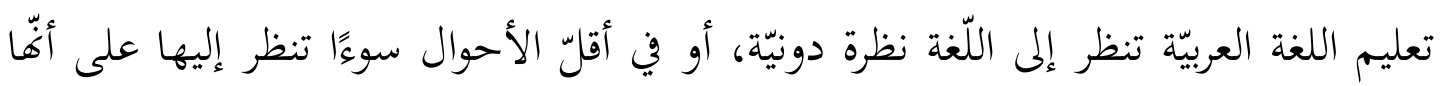

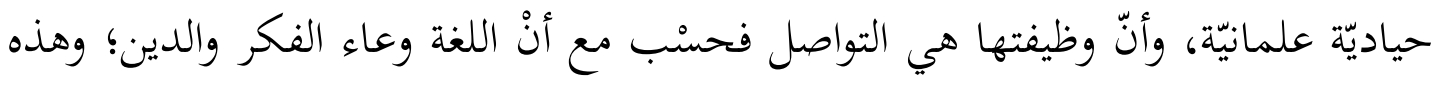

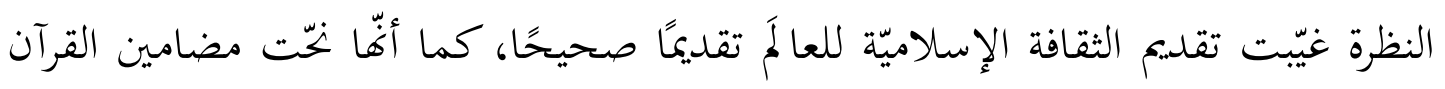

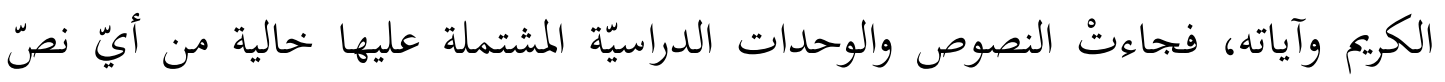

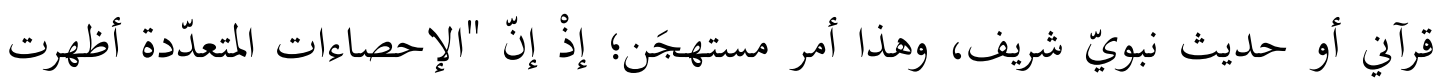

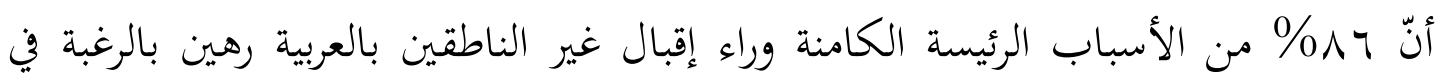

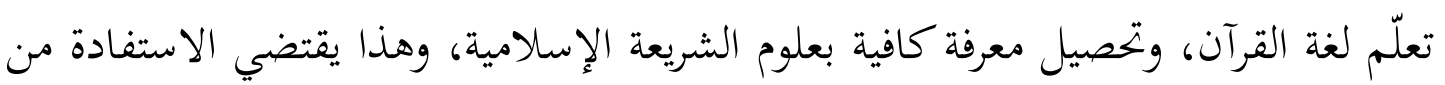

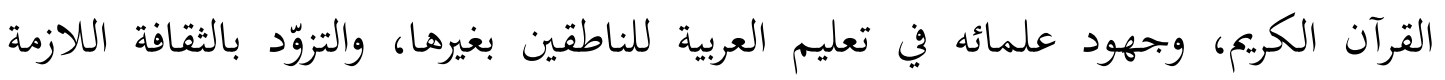




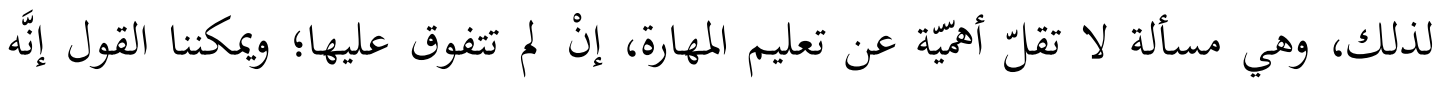

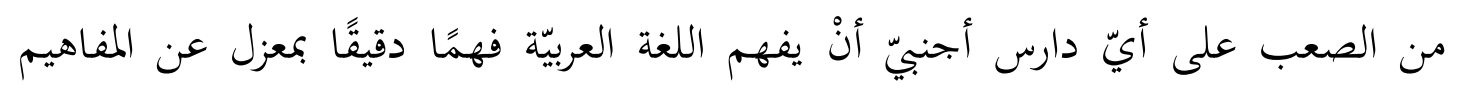

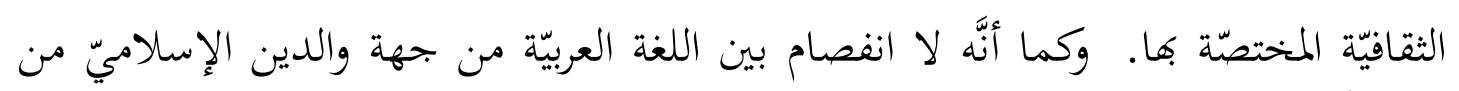

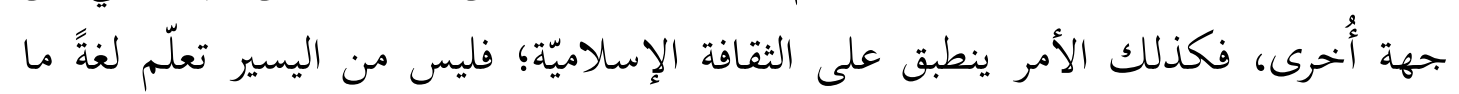

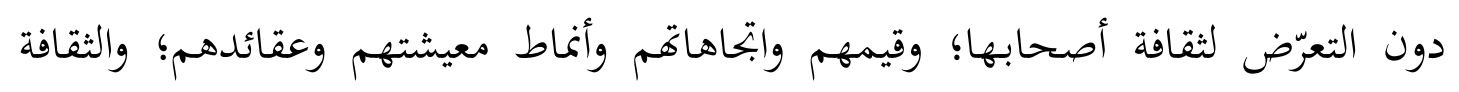

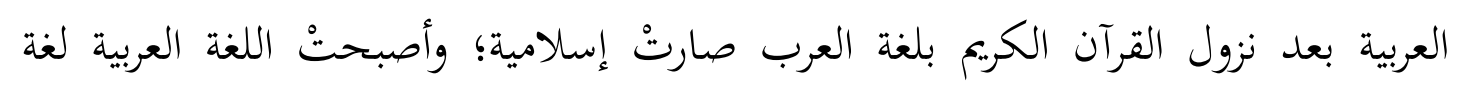

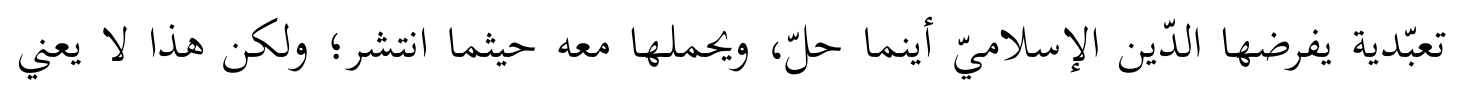

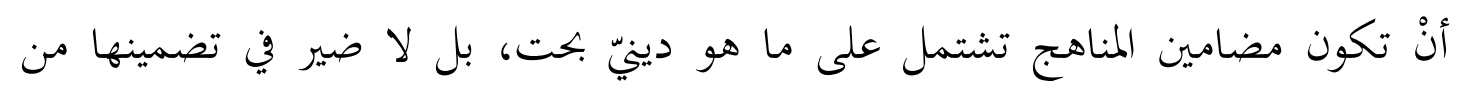

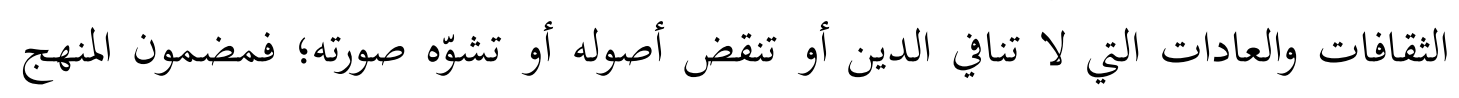

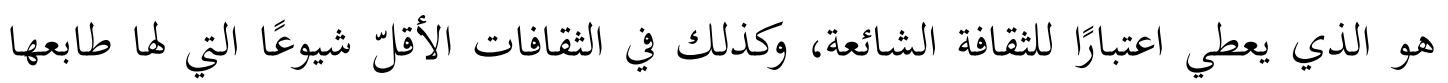

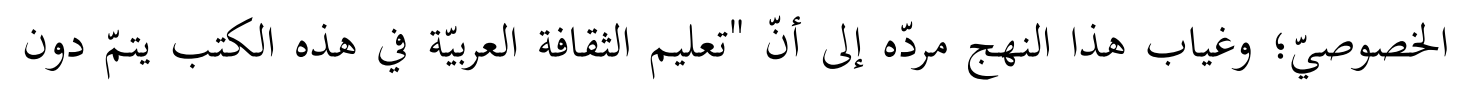
دراسة علميّة سابقة لها.

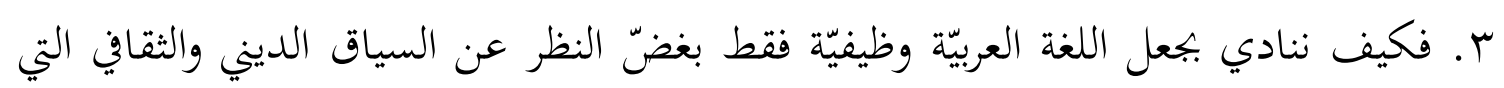

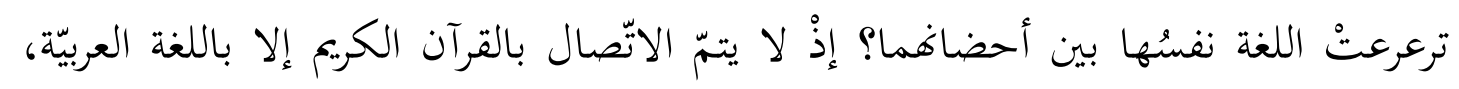

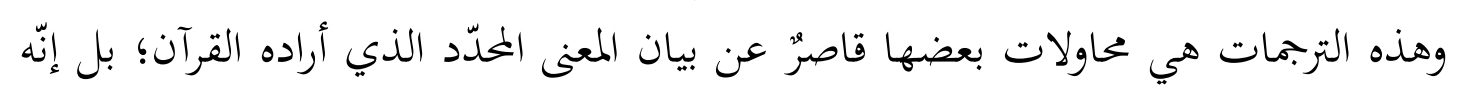

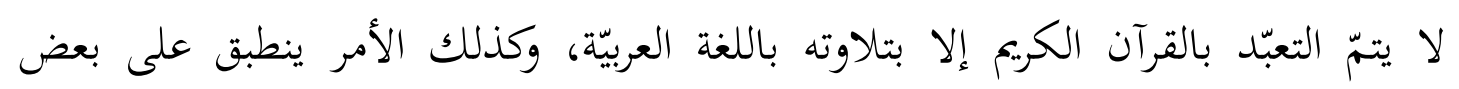

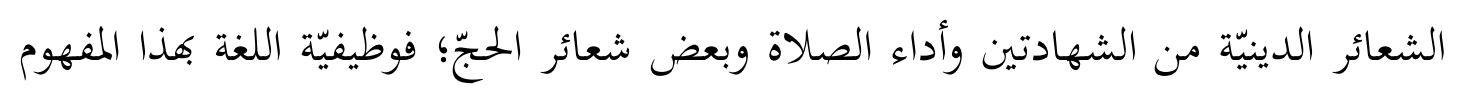

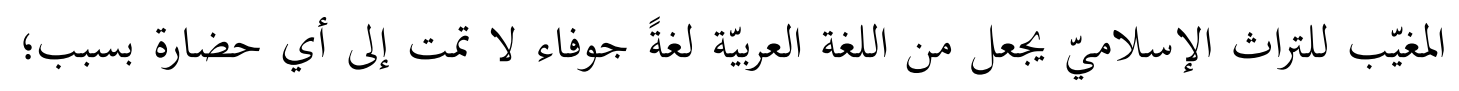

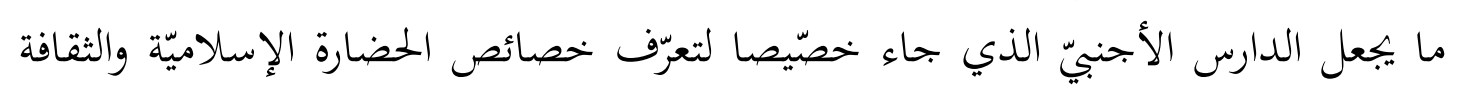
العربيّة والإسلامية زاهدًا في تعلّمها.

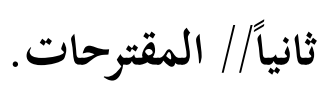

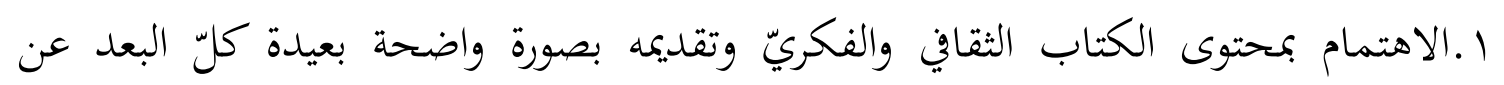

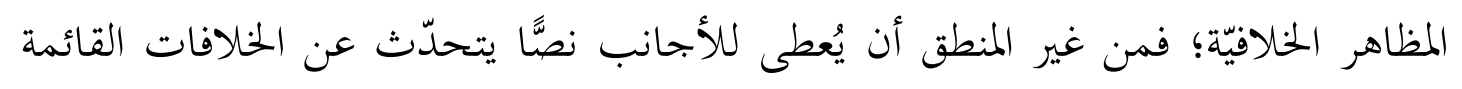

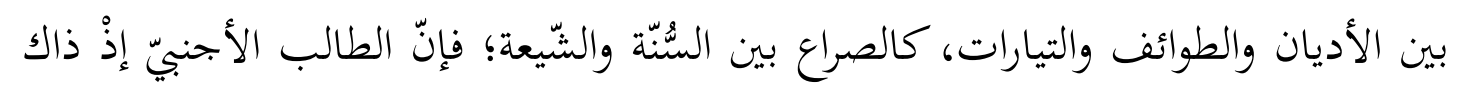

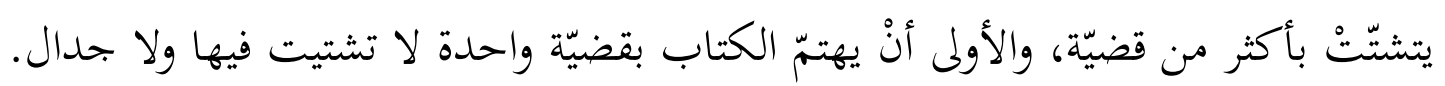

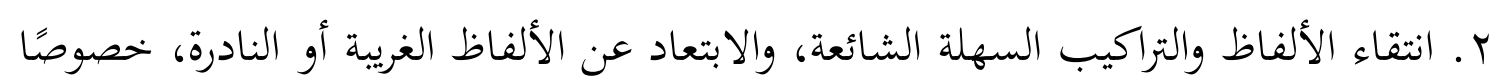

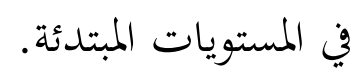


r. التنوّع في التمرينات والتدريبات مع بتنّب الإيغال فيها.

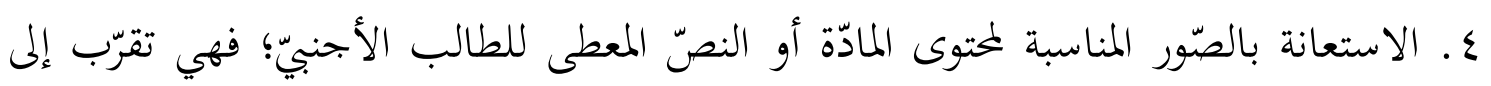
ذهنه الفكرة، وأن يكون هناك انسجام وملائمة بين الصورة وطبيعة الدرس.

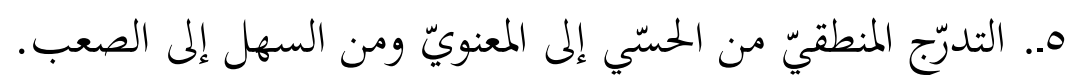
7 7. سلامة الموادّ المعروضة من الأخطاء اللغوية والعلميّة والتاريخيّة.

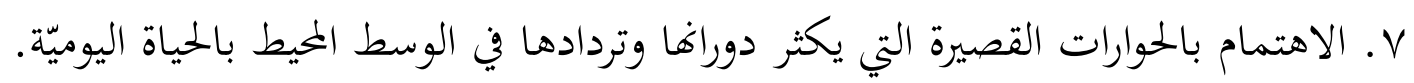

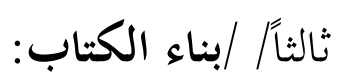

1. بناء الكتاب المختصّ بالناطقين بغير العربيّة يتطلّب جدولًا وخطّة يسير على وفقهما

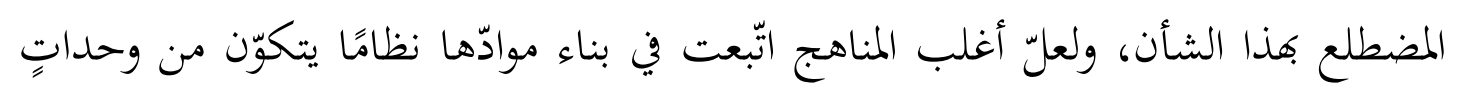

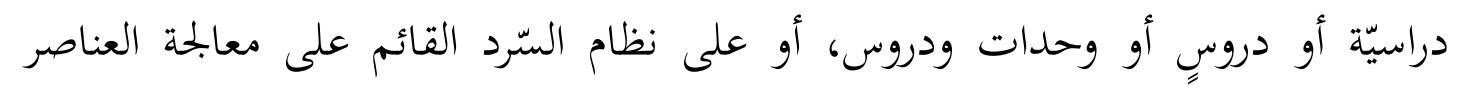
اللغويّة معالجحة فرديّة أو جماعيّة.

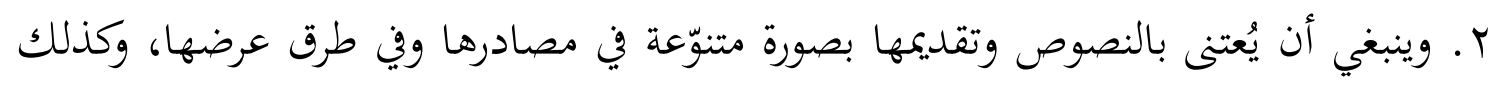

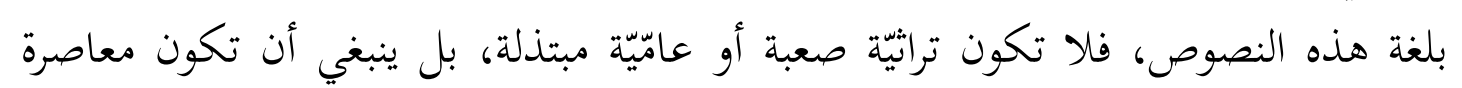
من لغة الثقافة والإعلام. r. وكذلك مراعاة اللغة الوسيطة وإباحة استعمالها بقذْر يقتضيه الموقف في المستويات المبتدئة، والابتعاد عنها في المستويات المتوسّطة والمتقدّمة إن أمكن.

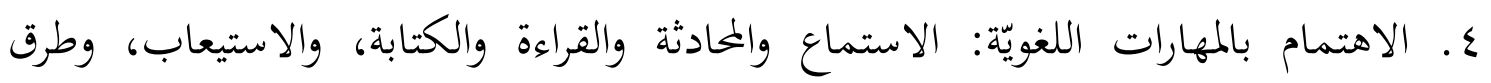

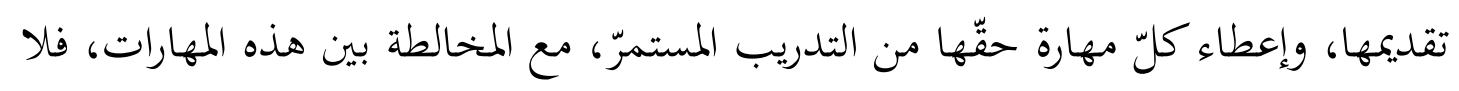

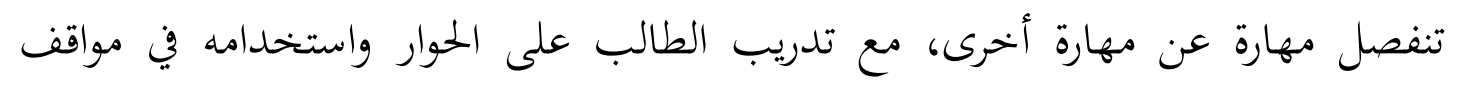

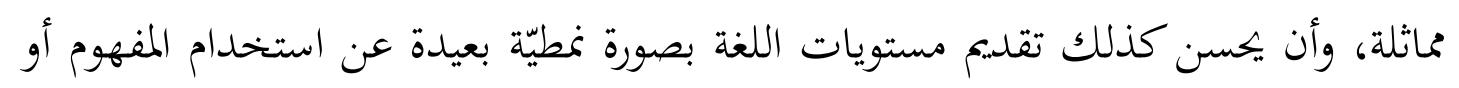
التعريف في أثناء شرح القواعد.

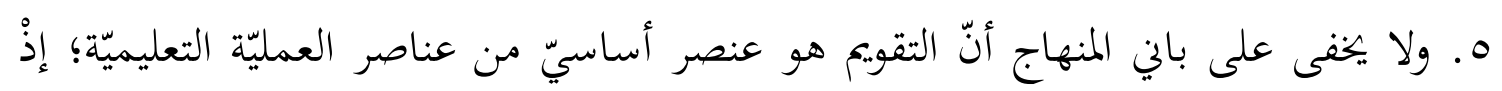

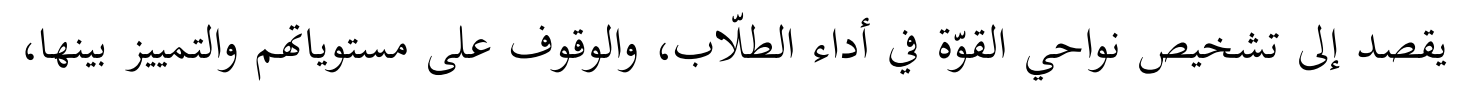
وتحديد مواطن الضعف والقوّة في محتوى المنهاج؛ ما يؤدّي إلى تطويره والتعديل عليه.

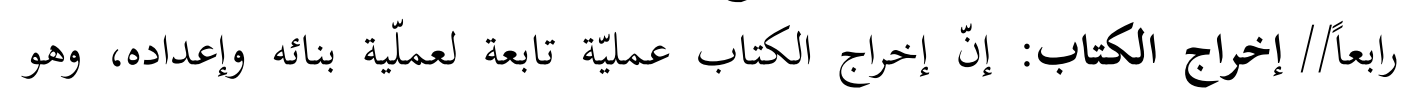

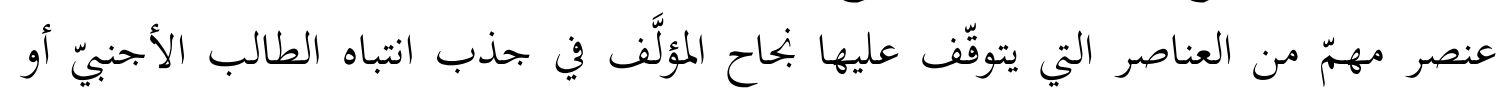

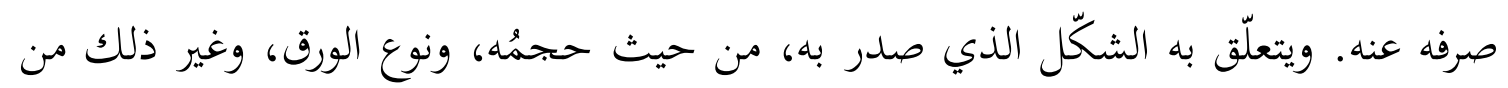


جوانب تتّصل بالشكل العامّ الذي صدر به الكتاب. والملاحظة أنّ بعض مؤلّفي كتب تعليم

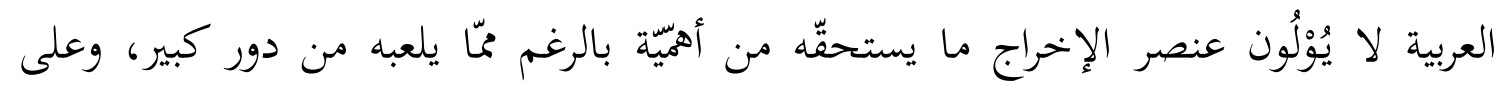

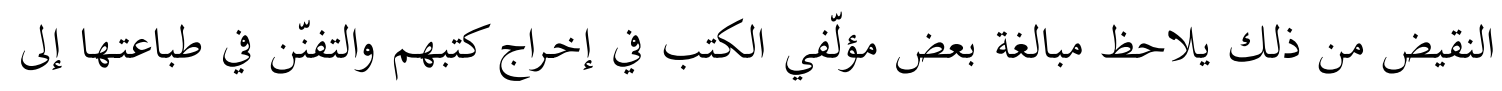

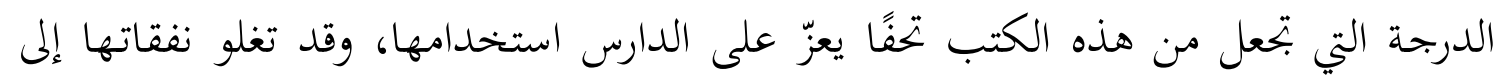

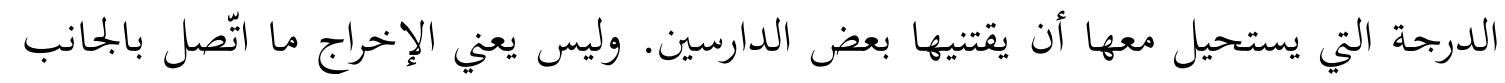

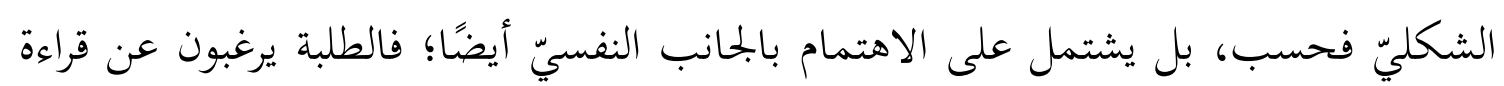

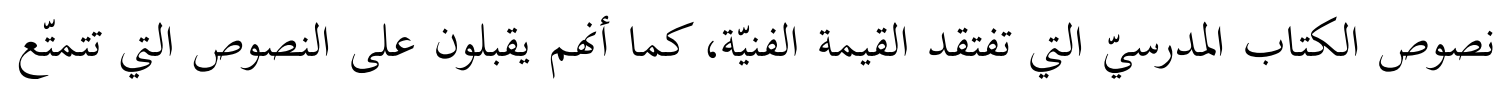
بالإخراج الفني الراقي.

\section{مصادر الدراسة}

إبراهيم محمد الشافعي وآخرون، المنهج المدرسي من منظور جاديل، الرياض، مكتبة

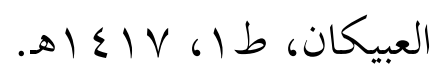

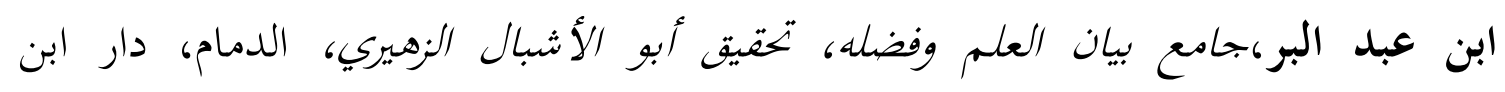

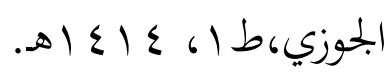

أحمد حسين القالي، المناهج بين النظرية والتطبيق، القاهرة، عالم الكتب، 990 أمدام.

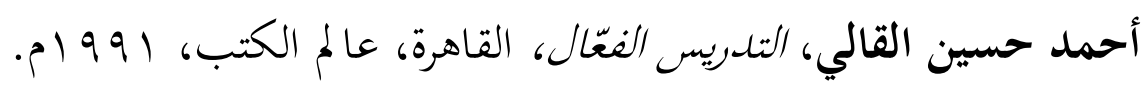

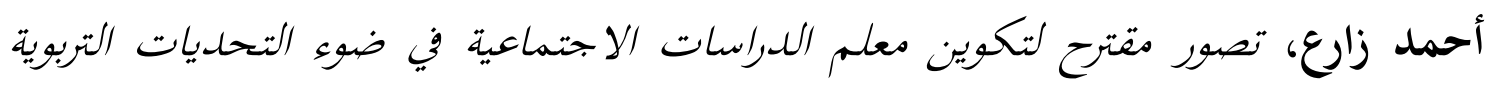

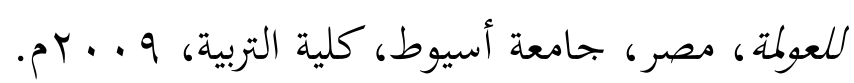

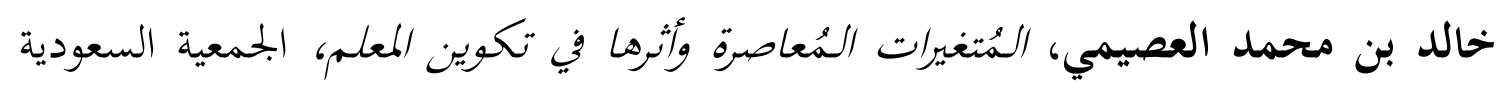
للعلوم والتربية النفسية، اللقاء السنوي (r ا (). خديجة عبد الززاق الحديثي، دراسات في كتاب سيبويه، الكويت، وكالة المطبوعات، . $19 \vee 7$ زياد حمدان محمد، تخطيط المنهج-الكتاب الملدرسي، الأردن، دار التربية الحديثة، م إـ اهـ. 
زين الدين محمد بن أبي بكر بن عبد القادر الرازي، مُختار الصّّحاح، بيروت، مؤسسة

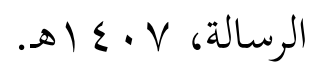
سالم مهدي محمود وآخرون، التربية الميدانية وأساسيات التدريس، الرياض، مكتبة العبيكان، ط ط اله 919 سليمان يوسف خاطر،منهج سيبويه في الاستشهاد بالقرآن، السعودية،مكتبة الرشد للنشر

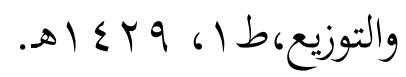

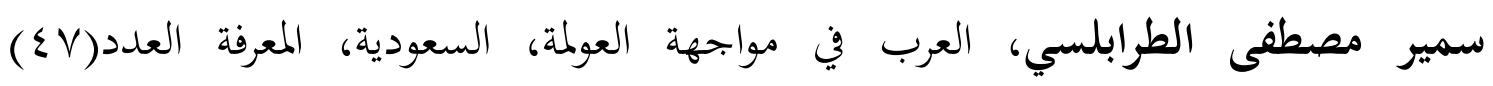

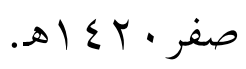
الثافعي محمد بن إدريس، الرسالة في أصول الفقه، القاهرة، دار الكتب العلمية، 901 ام.

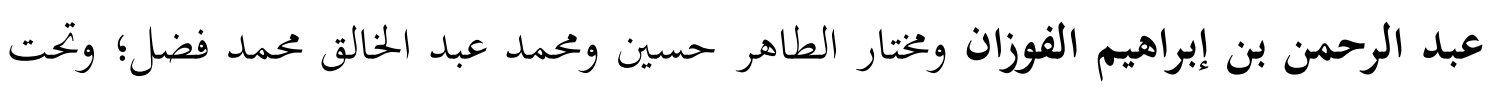

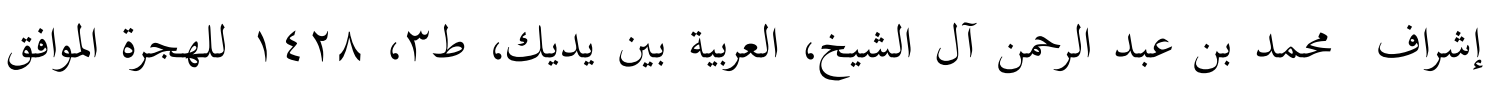

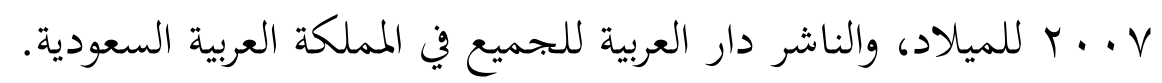

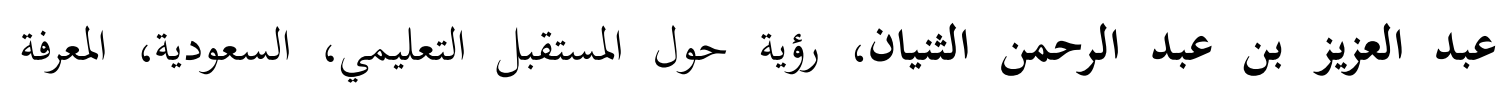

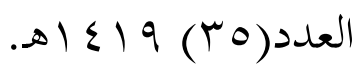

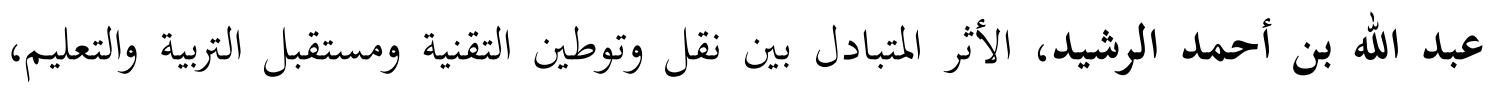

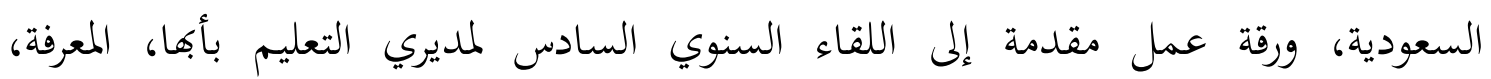

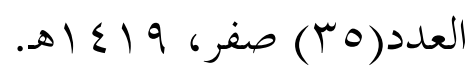

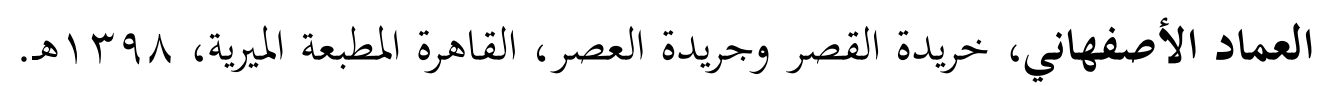

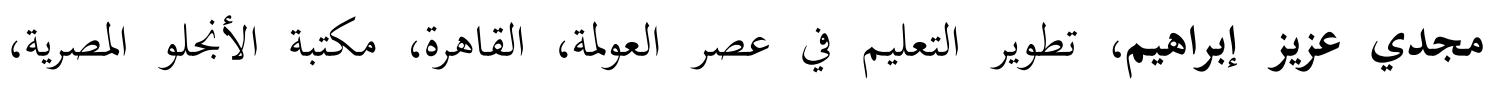
محمد بن معجب الحامد، تطور المناهج الدراسية بين الواقع والتطلعات، ورقة عمل مقدمة

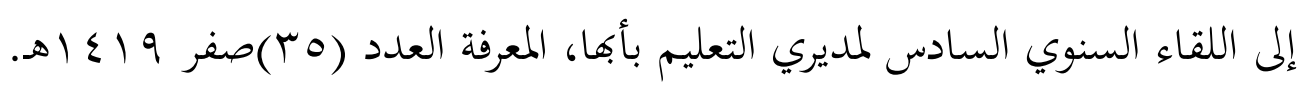

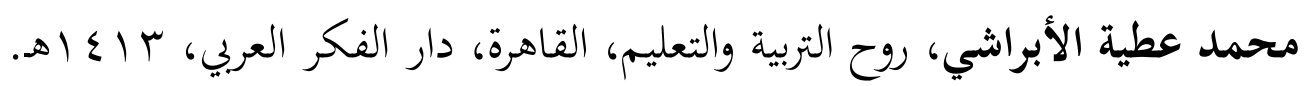

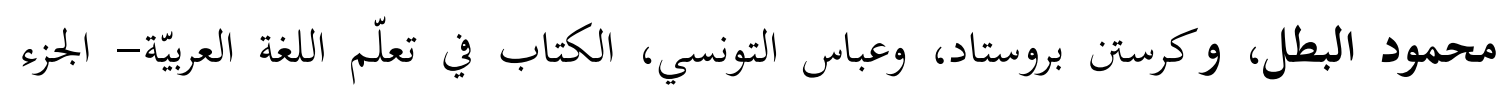

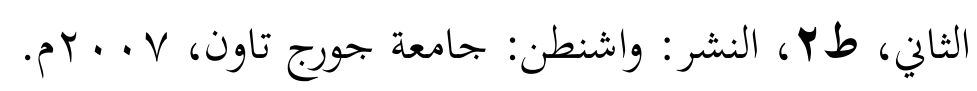
محمود الوكيل، الابحاهات الحديثة في تخطيط وتطوير المناهج، القاهرة، وزارة التربية والتعليم، تون، . $19 \wedge \mathrm{V}$ 
مصطفى عبد السلام، تطوير المناهج لتلبية متطلبات التنمية لمواجهة العولمة، مصر، المؤتمر

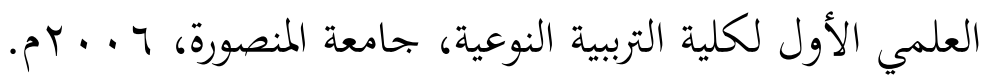

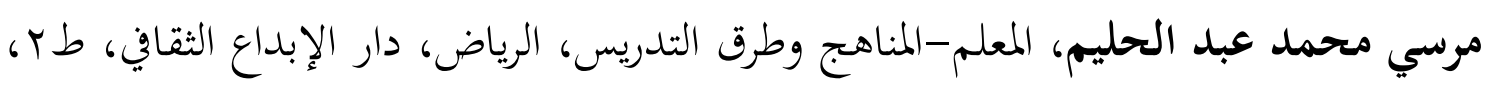
(1) 10 منير البعلبكي، المورد- قاموس انخليزي-عربي، بيروت، دار العلم للملايين، ط. با، 999 ام.

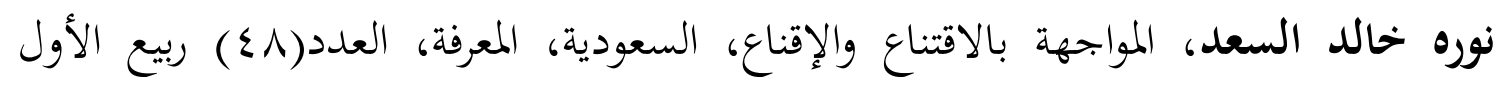

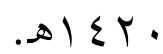
وثيقة استشراف مستقبل العمل التربوي في الدول الأعضاء بككتب التربية لدول الخليج، 9 يوسف قطامي، نماذج التدريس الصفي، عمان، دار الشروق للنشر والتوزيع، طب، 9919 ام. 